Prepared in cooperation with the National Park Service and National Water Quality Program National Park Service Water Quality Partnership

\title{
Perchlorate and Selected Metals in Water and Soil within Mount Rushmore National Memorial, South Dakota, 2011-15
}

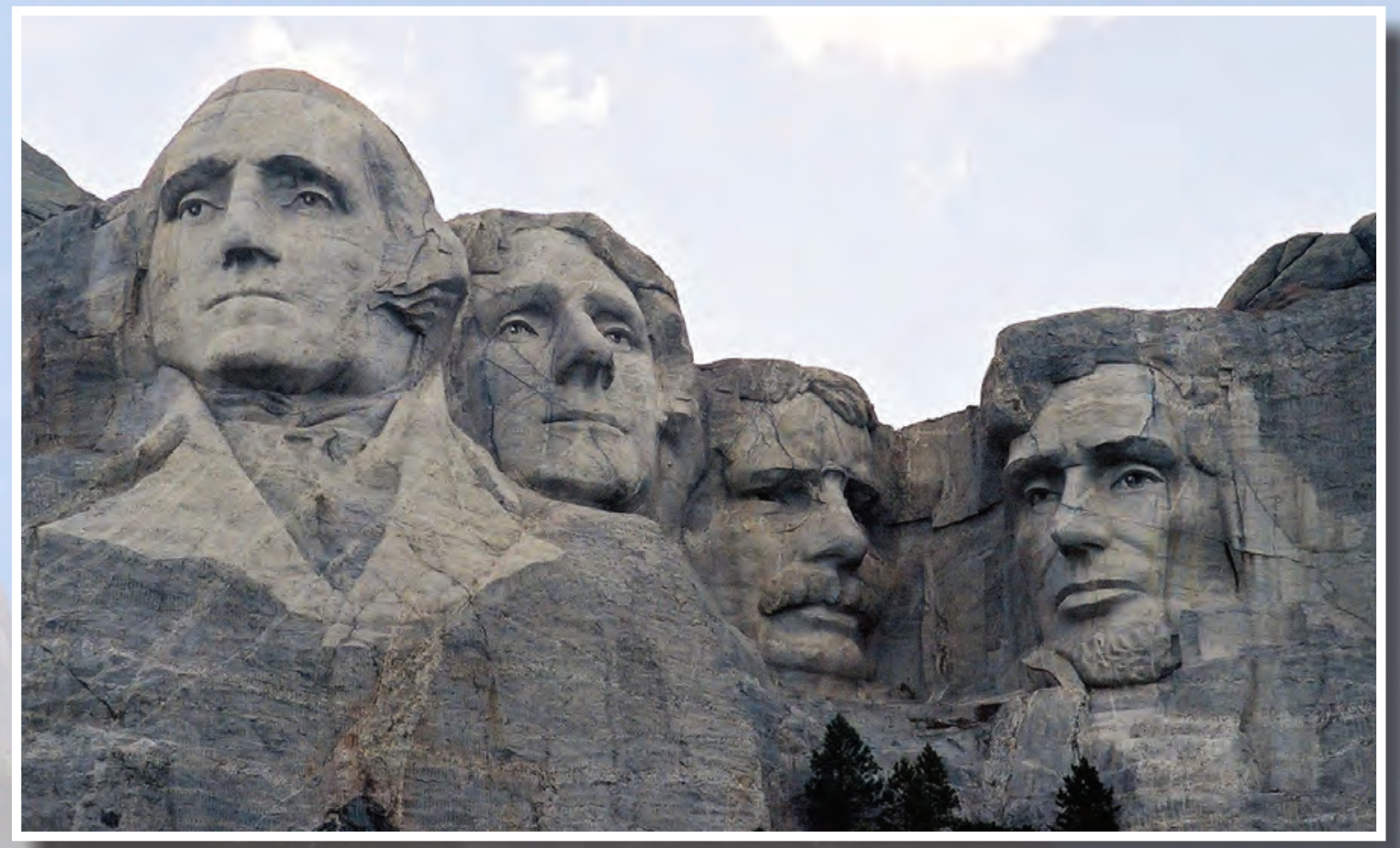

Scientific Investigations Report 2016-5030 
Cover photograph. Mount Rushmore National Memorial (Photograph courtesy of the National Park Service). 


\section{Perchlorate and Selected Metals in Water and Soil within Mount Rushmore National Memorial, South Dakota, 2011-15}

By Galen K. Hoogestraat and Barbara L. Rowe

Prepared in cooperation with the National Park Service and National Water Quality Program

National Park Service Water Quality Partnership

Scientific Investigations Report 2016-5030 


\title{
U.S. Department of the Interior SALLY JEWELL, Secretary
}

\section{U.S. Geological Survey Suzette M. Kimball, Director}

\author{
U.S. Geological Survey, Reston, Virginia: 2016
}

For more information on the USGS - the Federal source for science about the Earth, its natural and living resources, natural hazards, and the environment—visit http://www.usgs.gov or call 1-888-ASK-USGS.

For an overview of USGS information products, including maps, imagery, and publications, visit http://www.usgs.gov/pubprod/.

Any use of trade, firm, or product names is for descriptive purposes only and does not imply endorsement by the U.S. Government.

Although this information product, for the most part, is in the public domain, it also may contain copyrighted materials as noted in the text. Permission to reproduce copyrighted items must be secured from the copyright owner.

Suggested citation:

Hoogestraat, G.K., and Rowe, B.L., 2016, Perchlorate and selected metals in water and soil within Mount Rushmore National Memorial, South Dakota, 2011-15: U.S. Geological Survey Scientific Investigations Report 2016-5030, 29 p., http://dx.doi.org/10.3133/sir20165030.

ISSN 2328-0328 (online) 


\section{Contents}

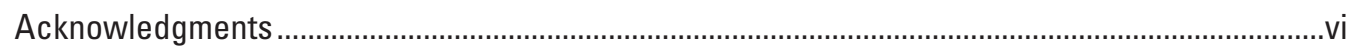

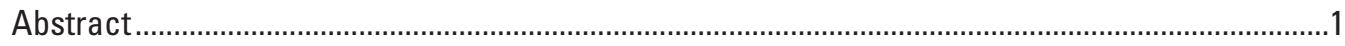

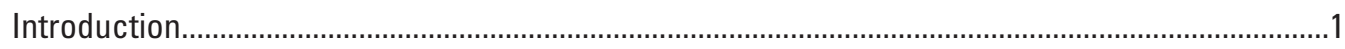

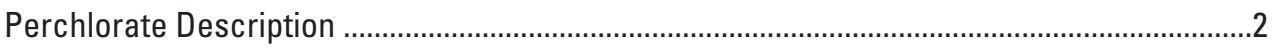

Metals Associated with Firework Displays ...............................................................................4

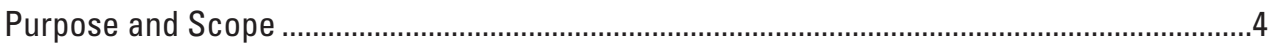

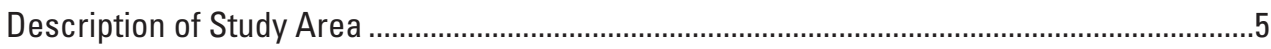

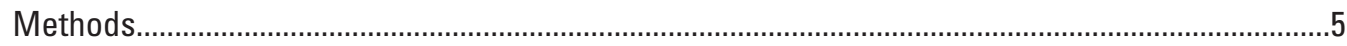

Selection and Description of Sampling Sites........................................................................5

Collection, Processing, and Analyses of Water Samples..........................................................8

Collection, Processing, and Analyses of Soil Samples ...............................................................

Quality Assurance and Quality Control .....................................................................................10

Perchlorate and Metal Occurrence at Mount Rushmore National Memorial ................................12

Field Properties of Water Samples .............................................................................................12

Perchlorate in Groundwater and Surface Water .................................................................17

Perchlorate in Soil Samples..................................................................................................19

Metal Concentrations in Groundwater and Surface Water .................................................. 19

Metal Concentrations in Soil Samples .......................................................................................19

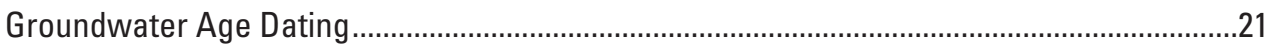

Implications of Perchlorate in Water and Soil........................................................................21

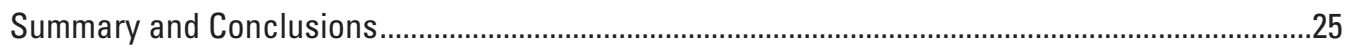

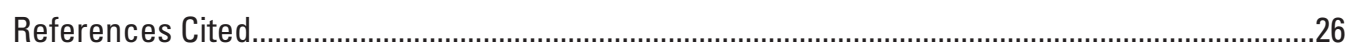

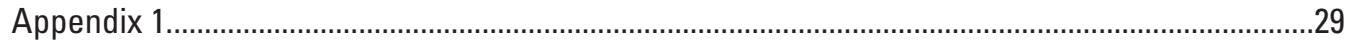




\section{Figures}

1. Maps showing major drainage basins and sampling locations within the study area, Mount Rushmore National Memorial.

2. Photograph showing collection of composite soil samples, Mount Rushmore National Memorial.

3. Box plot showing perchlorate concentration in selected groundwater and surface-water sites within and adjacent to Mount Rushmore National Memorial, 2011-15

4. Graphs showing perchlorate concentrations at eight sampling sites within Mount Rushmore National Memorial, 2011-15

5. Graph showing median concentrations for five selected metals in samples from groundwater and surface-water sites within and adjacent to Mount Rushmore National Memorial, 2011-15

6. Boxplots of arsenic concentrations in groundwater and surface-water samples within and adjacent to Mount Rushmore National Memorial, 2011-15...

7. Graphs showing concentrations of five selected metals and perchlorate in soil samples within Mount Rushmore National Memorial and reference sites, 2012-13.....23

\section{Tables}

1. Constituents measured and analyzed in water and soil within and adjacent to Mount Rushmore National Memorial, 2011-15.

2. Sites within and adjacent to Mount Rushmore National Memorial where water and soil samples were collected, 2011-15.

3. Water-quality information for groundwater and surface-water field blank and replicate samples within and adjacent to Mount Rushmore National Memorial, 2012-15

4. Perchlorate and selected metal concentrations and relative percent differences in replicate soil sample pairs collected within and adjacent to Mount Rushmore National Memorial, 2012-13

5. Statistical summary of water-quality information for groundwater and surface-water sampling sites within and adjacent to Mount Rushmore National Memorial, 2011-15.

6. Perchlorate and selected metal concentrations in soil samples collected within and adjacent to Mount Rushmore National Memorial, 2012-13.

7. Groundwater age dating results from wells within and adjacent to Mount Rushmore National Memorial, 2012-2013 


\section{Conversion Factors}

[U.S. customary units to International System of Units]

\begin{tabular}{|c|c|c|}
\hline Multiply & By & To obtain \\
\hline \multicolumn{3}{|c|}{ Length } \\
\hline inch (in.) & 2.54 & centimeter $(\mathrm{cm})$ \\
\hline foot $(\mathrm{ft})$ & 0.3048 & meter $(\mathrm{m})$ \\
\hline mile (mi) & 1.609 & kilometer (km) \\
\hline \multicolumn{3}{|c|}{ Area } \\
\hline acre & 0.4047 & hectare (ha) \\
\hline \multicolumn{3}{|c|}{ Volume } \\
\hline gallon (gal) & 3.785 & liter $(\mathrm{L})$ \\
\hline \multicolumn{3}{|c|}{ Mass } \\
\hline pound, avoirdupois (lb) & 0.4536 & kilogram $(\mathrm{kg})$ \\
\hline \multicolumn{3}{|c|}{ Flow rate } \\
\hline cubic foot per second $\left(\mathrm{ft}^{3} / \mathrm{s}\right)$ & 0.02832 & cubic meter per second $\left(\mathrm{m}^{3} / \mathrm{s}\right)$ \\
\hline
\end{tabular}

Temperature in degrees Celsius $\left({ }^{\circ} \mathrm{C}\right)$ may be converted to degrees Fahrenheit $\left({ }^{\circ} \mathrm{F}\right)$ as follows

$$
{ }^{\circ} \mathrm{F}=\left(1.8 \times{ }^{\circ} \mathrm{C}\right)+32 \text {. }
$$

Temperature in degrees Fahrenheit $\left({ }^{\circ} \mathrm{F}\right)$ may be converted to degrees Celsius $\left({ }^{\circ} \mathrm{C}\right)$ as follows

$$
{ }^{\circ} \mathrm{C}=\left({ }^{\circ} \mathrm{F}-32\right) / 1.8 \text {. }
$$

\section{Datums}

Horizontal coordinate information is referenced to the North American Datum of 1983 (NAD 83).

Vertical coordinate information is referenced to the North American Vertical Datum of 1988 (NAVD 88).

Elevation, as used in this report, refers to distance above the vertical datum.

\section{Supplemental Information}

Specific conductance is given in microsiemens per centimeter at 25 degrees Celsius $(\mu \mathrm{S} / \mathrm{cm})$.

Concentrations of chemical constituents in water are given in either milligrams per liter ( $\mathrm{mg} / \mathrm{L}$ ) or micrograms per liter $(\mu \mathrm{g} / \mathrm{L})$. Concentrations of chlorofluorocarbons in water are given in picograms per kilogram $(\mathrm{pg} / \mathrm{kg})$. Concentrations of chemical constituents in soil are given in milligrams per kilogram $(\mathrm{mg} / \mathrm{kg})$ or micrograms per kilogram $(\mu \mathrm{g} / \mathrm{kg})$.

Water year is the 12-month period, 0ctober 1 through September 30, and is designated by the calendar year in which it ends. 


\section{Abbreviations}

$<\quad$ less than

CFC chlorofluorocarbon

$\mathrm{ClO}_{4}^{-}$perchlorate

DO dissolved oxygen

EPA U.S. Environmental Protection Agency

MADEP Massachusetts Department of Environmental Protection

MCL Maximum Contaminant Level

MRL minimum reporting level

NPS National Park Service

RPD relative percent difference

SC specific conductance

USGS U.S. Geological Survey

\section{Acknowledgments}

The authors would like to acknowledge the facilities staff from Mount Rushmore National Memorial and the Black Hills National Forest for providing access to well sampling locations, operational information, and review of interpretive information provided in this report. 


\title{
Perchlorate and Selected Metals in Water and Soil within Mount Rushmore National Memorial, South Dakota, 2011-15
}

\author{
By Galen K. Hoogestraat and Barbara L. Rowe
}

\section{Abstract}

Mount Rushmore National Memorial is located in the east-central part of the Black Hills area of South Dakota and is challenged to provide drinking water to about 3 million annual visitors and year-round park personnel. An environmental concern to water resources within Mount Rushmore National Memorial has been the annual aerial fireworks display at the memorial for the Independence Day holiday during 19982009. A major concern of park management is the contamination of groundwater and surface water by perchlorate, which is used as an oxidizing agent in firework displays. A study by the U.S. Geological Survey, in cooperation with the National Park Service, was completed to characterize the occurrence of perchlorate and selected metals (constituents commonly associated with fireworks) in groundwater and surface water within and adjacent to Mount Rushmore National Memorial during 2011-15. Concentrations of perchlorate and metals in 106 water samples (collected from 6 groundwater sites and 14 surface-water sites) and 11 soil samples (collected from 11 soil sites) are reported.

Within the Mount Rushmore National Memorial boundary, perchlorate concentrations were greatest in the Lafferty Gulch drainage basin, ranging from less than 0.20 to 38 micrograms per liter $(\mu \mathrm{g} / \mathrm{L})$ in groundwater samples and from 2.2 to $54 \mu \mathrm{g} / \mathrm{L}$ in surface-water samples. Sites within the Starling Gulch drainage basin also had some evidence of perchlorate contamination, with concentrations ranging from 0.61 to $19 \mu \mathrm{g} / \mathrm{L}$. All groundwater and surface-water samples within the unnamed tributary to Grizzly Bear Creek drainage basin and reference sites outside the park boundary had concentrations less than $0.20 \mu \mathrm{g} / \mathrm{L}$. Perchlorate concentrations in samples collected at the 200-foot-deep production well (Well 1) ranged from 17 to $38 \mu \mathrm{g} / \mathrm{L}$ with a median of $23 \mu \mathrm{g} / \mathrm{L}$, whereas perchlorate concentrations in samples from the 500-foot-deep production well (Well 2) ranged from 2.1 to $17 \mu \mathrm{g} / \mathrm{L}$, with a median of $6.1 \mu \mathrm{g} / \mathrm{L}$. Perchlorate concentrations in samples of the treated groundwater were similar to the concentrations from Well 1, which was the predominant source of the water supply at Mount Rushmore National Memorial during the study period (2011-15). Springflow upstream from the production wells in the West Fork Lafferty Gulch drainage had the greatest perchlorate concentrations, ranging from 21 to $54 \mu \mathrm{g} / \mathrm{L}$. The groundwater site within Lafferty Gulch drainage basin but downstream from the park boundary also had a perchlorate concentration less than $0.20 \mu \mathrm{g} / \mathrm{L}$ in the one sample collected at the site. Water samples collected at reference sites generally had concentrations of metals within the same range of those sites within the Mount Rushmore National Memorial boundary, presenting little evidence of metal contamination due to anthropogenic factors within the park boundary. Soil samples were collected near most water sampling sites and within the Hall of Records Canyon where fireworks were launched. Perchlorate concentrations in soil were greatest in the West Fork Lafferty Gulch drainage and Hall of Records Canyon, which are topographically higher than the two groundwater wells.

The perchlorate concentrations in groundwater and surface water within Lafferty Gulch drainage basin during 2011-15 were greater than the U.S. Environmental Protection Agency's Interim Drinking Water Health Advisory benchmark of $15 \mu \mathrm{g} / \mathrm{L}$. The perchlorate concentrations in the Mount Rushmore water supply relative to this benchmark are of concern; however, this health advisory is based on the assumption that consumers are using the supply as their primary water source and currently is not a regulated standard. The groundwater system at West Fork Lafferty Gulch is highly susceptible to contamination by way of recharge and is isolated from downstream movement by an intrusive body acting as a dam, which may explain why a contamination problem is not likely to disappear or disperse, as could happen in larger aquifer systems. The observed deposition of firework debris within Lafferty Gulch drainage basin coupled with the lack of alternative perchlorate sources indicates that past firework displays are the most probable source of perchlorate contamination.

\section{Introduction}

Mount Rushmore National Memorial showcases four of the Nation's most venerated presidents carved in a granitic monument that serves as the focal point within the 1,280 acres 
of National Park Service (NPS) land in the Black Hills of western South Dakota. The carved memorial is set in the rugged terrain that was created by the intrusion of granite and pegmatite into existing country rock and subsequent erosion of overlying sedimentary units. A challenge for NPS managers is to provide drinking water to about 3 million annual visitors and year-round park personnel. About 7 million gallons of drinking water each year are pumped from two wells, which are 200 and 500 feet (ft) deep, located about 0.5 mile (mi) northeast of the memorial and visitor center within Lafferty Gulch drainage basin. The 200-ft production well (Well 1, location L-3 on fig. 1) was the single drinking-water source for Mount Rushmore National Memorial from 1967 to 2010. A 500-ft well (Well 2, location L-4) was drilled in 2010 to supplement drinking water provided by Well 1 .

An environmental concern to water resources within Mount Rushmore National Memorial has been the annual aerial display of fireworks at the memorial for the Independence Day holiday during 1998-2009. In preparation for the firework displays, pyrotechnics were stored in the Hall of Records that is located west and behind the sculptured heads. Fireworks were launched from the adjacent Hall of Records Canyon that ranges in depth from 80 to $120 \mathrm{ft}$ below the Hall of Records and is approximately $500 \mathrm{ft}$ above the visitor center (fig. 1). The fireworks were loaded in above-ground polyethylene mortar tubes that were placed in racks constructed from 1- and 2-inch (in.) pine boards (National Park Service, written commun., 2009). The sights and sounds of each explosion associated with the fireworks are the result of several chemical reactions within the stars - oxidations and reductions taking place within the firework as it ascends into the sky. Perchlorate is an oxygenate of choice for fireworks because it is stable and contains oxygen-rich chlorates with chlorine in oxidation state +7 , which increases the velocity and range of the display (Trumpolt and others, 2005). A concern by park management is the potential for contamination of groundwater and surface water by perchlorate. Perchlorate is exceptionally stable in the environment, making the compound a persistent and problematic pollutant once groundwater is contaminated (Urbansky, 2002). The carving of Mount Rushmore National Memorial was accomplished using dynamite as the blasting agent during 1927-41 (National Park Service, 2016). Dynamite is an explosive that contains nitroglycerin and diatomaceous earth or other adsorbent substances but does not intentionally contain perchlorate; therefore, the rock blasting used to carve Mount Rushmore National Memorial is not a likely source of perchlorate in groundwater or surface water during 2011-15.

To address concerns about water quality related to fireworks displays, the U.S. Geological Survey, in cooperation with the National Park Service, completed a study to characterize the occurrence of perchlorate and selected metals (constituents commonly associated with fireworks) in groundwater and surface water within and adjacent to Mount Rushmore National Memorial during 2011-15. For this study, concentrations of perchlorate and metals were analyzed in 106 water samples and 11 soil samples.

\section{Perchlorate Description}

Perchlorate $\left(\mathrm{ClO}_{4}^{-}\right)$is a naturally occurring and manmade compound that is a component in rocket fuels, fireworks, and some explosives (Trumpolt and others, 2005) and has been detected in many water supplies throughout the country. Most documented occurrences of perchlorate have been related to military and chemical-manufacturing operations; however, several studies have documented the presence of perchlorate in nitrate-bearing minerals from Chile that have been or are still being used as fertilizers in the United States (Kalkhoff and others, 2010). Research regarding water and soil contamination from perchlorate used in firework displays is limited to a few location-specific case studies. Wilkin and others (2007) documented perchlorate concentrations for municipal firework displays over Wintersmith Lake, Oklahoma. In that study, perchlorate background concentrations in surface water ranged from 0.005 to 0.081 microgram per liter $(\mu \mathrm{g} / \mathrm{L})$ prior to the firework display, spiked at $44.2 \mu \mathrm{g} / \mathrm{L}$ after the display, and decreased toward background levels within 20-80 days, indicating that degradation of perchlorate occurred in a relatively short time period. The Massachusetts Department of Environmental Protection (MADEP) performed a fireworks residue field test at the University of Massachusetts Dartmouth Campus, where 11 years of firework displays resulted in perchlorate contamination in soil and groundwater within the study area (Massachusetts Department of Environmental Protection, 2007). Analytical results indicated that the groundwater samples collected after a firework display contained perchlorate concentrations ranging from less than detection levels to $62.2 \mu \mathrm{g} / \mathrm{L}$. Surficial soil samples within the area also were collected, and analytical results from samples prior to firework displays showed no detections of perchlorate; however, perchlorate in soils after the display had measured concentrations of 560 micrograms per kilogram $(\mu \mathrm{g} / \mathrm{kg})$. The MADEP research revealed that elevated perchlorate concentrations seem to be from the residual of multiple firework displays conducted at a single site over time and that the perchlorate contamination is dependent on the amount and type of perchlorate used in the firework display. Mechanisms of perchlorate contamination include atmospheric fallout of fine particulates from the deflagration of aerial shells, debris "duds" that fail to ignite and plummet to the earth, wide area deposition and transport of shell fragments and paper debris emanating from ground-based launching operations as well as aerial bursts, and "misfires" from shells that do not launch from the mortar (Massachusetts Department of Environmental Protection, 2007). Fallout of fine particulates is thought to occur in a uniform manner, whereas deposition of shell fragments and debris are irregular and are dependent on wind conditions, terrestrial features, and cleanup practices.

Perchlorate absorbs poorly to most geologic materials, naturally attenuates only in facultative anaerobic environments, and is highly mobilized in groundwater (Gajjala, 2011). An adsorption test by Wilkin and others (2007) indicated that 


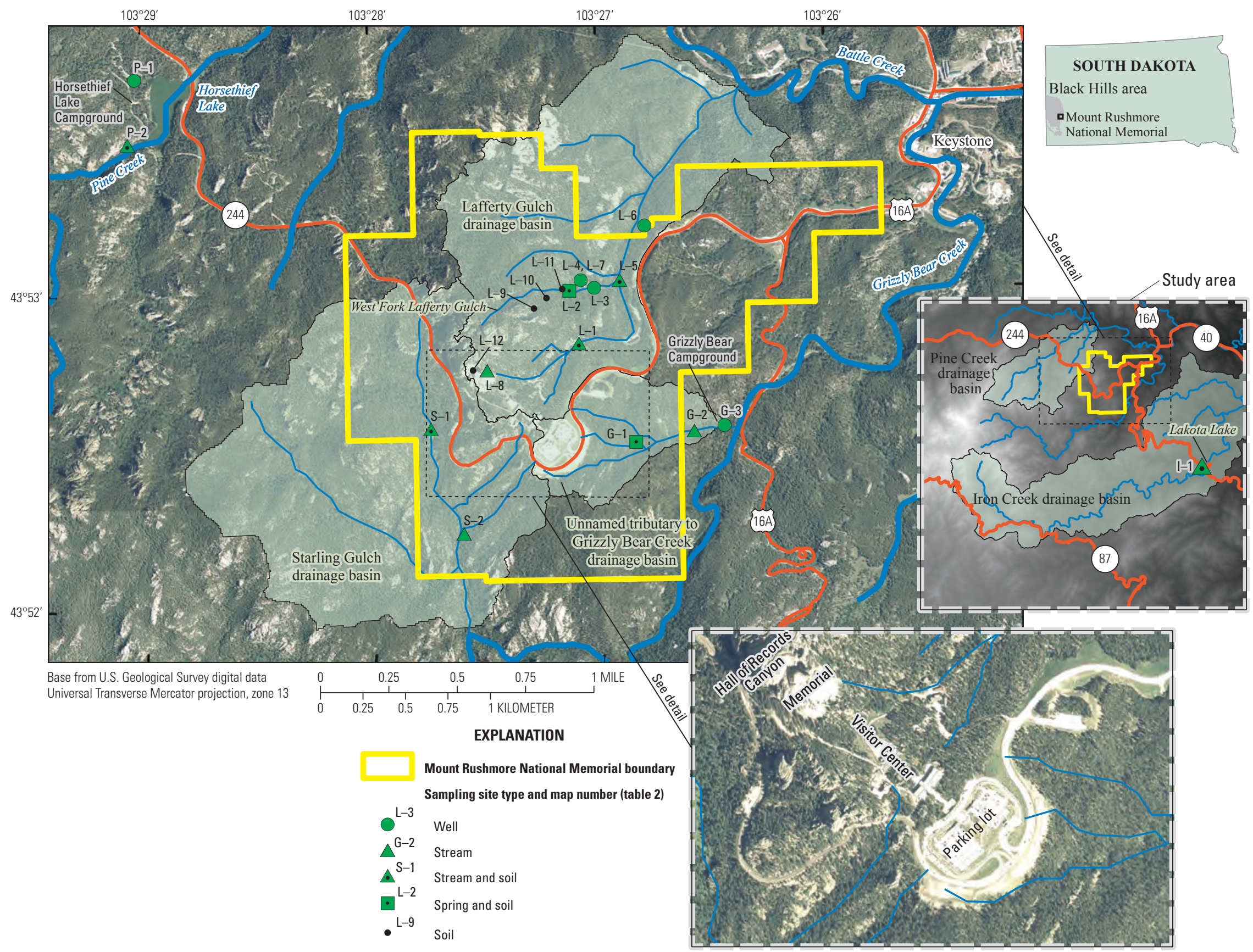

Figure 1. Major drainage basins and sampling locations within the study area, Mount Rushmore National Memorial. 
sediments underlying the water column have a limited capacity $(10 \mu \mathrm{g} / \mathrm{kg})$ to remove perchlorate by chemical adsorption. In addition, aerobic conditions, such as those at Mount Rushmore National Memorial documented as part of this study, are not conducive to microbial degradation of perchlorate. Perchlorate biodegradation in the environment requires anaerobic conditions, an adequate carbon source, and an active perchlorate-degrading microbial population (Tipton and others, 2003). In addition, the reduced travel time from the source of recharge to the production wells and the complex hydrogeologic setting of the Mount Rushmore National Memorial area do not readily allow for the dilution or natural attenuation of water prior to use as drinking water.

Physical and chemical properties that allow perchlorate to persist in the environment for many decades may ecologically pose a risk to aquatic ecosystems (Yu and others, 2004; Sandeep and Patiño, 2007). Perchlorate is known to disrupt the thyroid hormone homeostasis in several species including humans (Smith and others, 2001) and to target bone marrow and muscle at high concentrations (Urbansky, 1998; U.S. Environmental Protection Agency, 2005). Perchlorate was included on the U.S. Environmental Protection Agency (EPA) Unregulated Contaminant Monitoring Lists 1 and 2, and currently (2015) is on the EPA Contaminant Candidate List 3 (U.S. Environmental Protection Agency, 2015). An interim EPA Health Advisory was set at $15 \mu \mathrm{g} / \mathrm{L}$ based on the recommendations from the National Research Council of the National Academies (U.S. Environmental Protection Agency, 2008). The EPA Health Advisories serve as informal technical guidance to assist Federal, State, and local officials, and managers of public or community water systems in protecting public health when emergency spills or contamination situations occur. The EPA Health Advisories are not legally enforceable Federal standards and are subject to change as new information becomes available. Some States, however, have established standards for perchlorate that are more stringent than the interim EPA Health Advisory, such as Massachusetts at $2 \mu \mathrm{g} / \mathrm{L}$ (Massachusetts Department of Environmental Protection, 2006) and California at $6 \mu \mathrm{g} / \mathrm{L}$ (California Department of Public Health, 2007). A standard of $5 \mu \mathrm{g} / \mathrm{L}$ was proposed in New Jersey but was rejected (Murray, 2010).

Perchlorate concentrations in groundwater have been documented by various research agencies in the United States. Parker and others (2007) sampled 137 wells within the conterminous United States, where 58 percent of samples had perchlorate concentrations less than the minimum reporting level of $0.12 \mu \mathrm{g} / \mathrm{L}$ and only 9 percent of samples had concentrations greater than $1 \mu \mathrm{g} / \mathrm{L}$ (maximum of $10.4 \mu \mathrm{g} / \mathrm{L}$ ). Findings from a study of the High Plains area of Texas and New Mexico indicate that the occurrence of low perchlorate concentrations could be associated with atmospheric deposition rather than point-source contamination (Rajagopalan and others, 2006). Kalkhoff and others (2010) sampled 146 groundwater sites and 171 surface-water sites within the conterminous United States and determined that 43 percent of groundwater samples and 19 percent of surface-water samples had concentrations of perchlorate equal to or greater than the reporting level of $0.04 \mu \mathrm{g} / \mathrm{L}$. Only one surface-water sample and one groundwater sample had perchlorate concentrations greater than $5 \mu \mathrm{g} / \mathrm{L}$.

\section{Metals Associated with Firework Displays}

Potential sources of metals in water resources within Mount Rushmore National Memorial include fireworks displays at the memorial and the natural occurrence of metals in the granite and schists that constitute the lithology of the Mount Rushmore National Memorial area (Redden and DeWitt, 2008). Major and minor elements that naturally occur at concentrations greater than 5,000 milligrams per kilogram $(\mathrm{mg} / \mathrm{kg})$ in the central part of the Black Hills include aluminum, calcium, iron, manganese, magnesium, potassium, and titanium (Duke and others, 1992). In addition, metals that may occur naturally at concentrations greater than $100 \mathrm{mg} / \mathrm{kg}$ include lithium, barium, and strontium; and low-level concentrations may occur for antimony, arsenic, cobalt, copper, lead, zinc, and nickel (Duke and others, 1992). These naturally occurring metals also are used to generate pyrotechnic stars that produce intense light when ignited during firework displays. The blast charge inside a shell ignites the spherical stars that are rolled from metals, salts, and adhesives. The amount of energy released varies by element and is characterized by a particular wavelength that results in bright flashes of color from specific chemicals (Conkling, 1990). Without the addition of a coloring agent, the fuel burning in a firework would produce an almost white light (Steinhauser and others, 2008). For example, lithium and strontium are used to create reds, barium is used for greens, copper is used for purples and blues, titanium gives silver-white, aluminum appears yellow-white, and iron gives a gold effect (Russell, 2000). An example case study of metals contamination by fireworks is provided by Steinhauser and others (2008), who noted increased levels of barium and strontium in precipitation that fell during and after a fireworks display in Austria.

\section{Purpose and Scope}

The purpose of this report is to characterize the occurrence of perchlorate and selected metals (constituents commonly associated with fireworks) in groundwater and surface water within and adjacent to Mount Rushmore National Memorial during 2011-15. Concentrations of perchlorate and metals in 106 water samples and 11 soil samples are reported herein. Samples were collected from 6 groundwater sites, 14 surface-water sites, and 11 soil sites. Information about field properties of water samples and approximate groundwater ages also are presented. A general description of probable perchlorate sources is presented using information collected during 2011-15. 


\section{Description of Study Area}

Mount Rushmore National Memorial is located in the east-central part of the Black Hills region of South Dakota, near the town of Keystone (fig. 1). The summit of Mount Rushmore is at an elevation of 5,725 ft above the North American Vertical Datum of 1988 (NAVD 88), with elevations as low as $4,420 \mathrm{ft}$ above NAVD 88 in the lower valleys elsewhere within the park boundary. The carving at Mount Rushmore National Memorial and most surficial features in the western part of the park consist of granite, and virtually all other rocks within the memorial are pegmatite or schist (Powell and others, 1973). The memorial is on the northeast side of an area underlain by the Harney Peak Granite. The area to the west of the park boundary extending to Horsethief Lake (fig. 1) is occupied entirely by granite. Pegmatite sills and dikes are abundant for about a mile east of Mount Rushmore National Memorial (Powell and others, 1973).

Localized aquifers occur in the Precambrian igneous and metamorphic rocks that are not continuous, and groundwater flow is mainly controlled by secondary permeability caused by fracturing and weathering (Carter and others, 2002). Where the fractures in these Precambrian rocks are saturated, unconfined (water-table) conditions generally occur and topography can strongly control groundwater-flow directions (Driscoll and others, 2002). Fractures and joints within the granite and pegmatite rapidly transmit large quantities of recharged water to the wells located in Lafferty Gulch Basin (Powell and others, 1973). Recharge to the localized Precambrian aquifers also may result from large infiltration rates from permeable surficial deposits predominantly consisting of colluvium (Rahn, 1990).

Surface-water divides within the park unit are distinct, originate near the memorial, and separate three drainage basins: Lafferty Gulch, which flows southwest to northeast and drains the northern area of park unit to Battle Creek; unnamed tributaries to the south and east of the memorial that drain to Grizzly Bear Creek; and Starling Gulch, which trends north to south and drains the western flank of the park unit towards Grizzly Bear Creek (fig. 1). Powell and others (1973) refer to the drainage basin for the eastern tributaries to Grizzly Bear Creek as the East Boundary Basin.

Precipitation in the vicinity of Mount Rushmore National Memorial averaged about 21.5 in. annually during 1981-2010 (National Oceanic and Atmospheric Administration, 2015). Annual precipitation during water years 2011-14 (mean of 22.9 in.) was above the previous 30 -year mean, except for a very dry 2012 when 16.2 in. of precipitation was recorded at the Mount Rushmore National Memorial weather station (National Oceanic and Atmospheric Administration, 2015); a water year is the 12-month period, October 1 through September 30, and is designated by the calendar year in which it ends. The greatest precipitation total (27.7 in.) during the same span was recorded in water year 2014. Streamflow conditions during the study period were typical for the region and did not exhibit extreme high or low mean annual streamflow.
Mean annual streamflow in Battle Creek near Keystone (U.S. Geological Survey [USGS] streamgage 06404000, about 6 mi downstream [east] from Keystone) during water years 1962-2014 was 9.39 cubic feet per second $\left(\mathrm{ft}^{3} / \mathrm{s}\right)$, and during the study period (water years 2011-15) ranged from $1.97 \mathrm{ft}^{3} / \mathrm{s}$ in water year 2012 to $34.4 \mathrm{ft}^{3} / \mathrm{s}$ in water year 2015 (U.S. Geological Survey, 2016a).

\section{Methods}

Water and soil samples were collected during 2011-15 to provide a characterization of perchlorate and metals concentrations (table 1) in water resources within Mount Rushmore National Memorial. Several of the metals in table 1 are known to be present in fireworks, but the list includes other metals used to only to characterize water and soil differences among sites (such as calcium or arsenic). Sites were selected in each of the three major drainage basins within the park boundary, and sites in drainage basins adjacent to the park were selected to be used as reference comparisons. Sampling visits occurred during May through August in 2011-14, with two additional visits during the winter months in December 2014 and February 2015. Soil samples were collected once near most sites where water samples were collected and also at four locations near the area where firework displays were launched in previous years. The collection, processing, laboratory analyses, and qualityassurance procedures are described in the following sections.

\section{Selection and Description of Sampling Sites}

Mount Rushmore National Memorial contains three primary drainage basins that all intersect at a location near the memorial and visitor center (fig. 1). Sites sampled in this study (table 2; fig. 1) were located within these three basins with additional sites sampled in two adjacent drainage basins used as reference locations. The following section describes each site in relation to its hydrology and use in sampling design for this study, using the map numbers (table 2; fig. 1) for short identifiers in discussion.

Within the Lafferty Gulch drainage basin, 12 sites were sampled for surface water, groundwater, or soil. Site L-1 is a stream site located directly downstream from the effluent discharge point for the Mount Rushmore National Memorial wastewater treatment plant. Treated wastewater constituted most of the flow at this site when sampled; thus, water from this site originated from the production wells (sites L-3 and L-4) prior to its use at Mount Rushmore National Memorial. The L-1 site is located in a separate subdrainage basin from the production wells, which are located in West Fork Lafferty Gulch. Site L-2 is a spring site that creates a shallow stream in West Fork Lafferty Gulch, located just upstream from the production wells. Springflow measurements were not collected during this study; however, flows during non-runoff conditions were consistent with those measured in Rahn (1990) at less 
Table 1. Constituents measured and analyzed in water and soil within and adjacent to Mount Rushmore National Memorial, 2011-15.

[GW, groundwater; SW, surface water; X, measured; --, not available; $\mathrm{mg} / \mathrm{L}$, milligrams per liter; $\mu \mathrm{S} / \mathrm{cm}$, microsiemens per centimeter at 25 degrees Celsius; ${ }^{\circ} \mathrm{C}$, degrees Celsius; $\mu \mathrm{g} / \mathrm{L}$, micrograms per liter; $\mu \mathrm{g} / \mathrm{kg}$, micrograms per kilogram; $\mathrm{mg} / \mathrm{kg}$, milligrams per kilogram]

\begin{tabular}{|c|c|c|c|c|}
\hline \multirow{2}{*}{ Constituent } & \multicolumn{3}{|c|}{ Medium sampled } & \multirow{2}{*}{ Units } \\
\hline & GW & sW & Soil & \\
\hline \multicolumn{5}{|c|}{ Field properties } \\
\hline Dissolved oxygen & $\mathrm{X}$ & $X$ & -- & $\mathrm{mg} / \mathrm{L}$ \\
\hline $\mathrm{pH}$ & $\mathrm{X}$ & $\mathrm{X}$ & -- & standard units \\
\hline Specific conductance & $\mathrm{X}$ & $\mathrm{X}$ & -- & $\mu \mathrm{S} / \mathrm{cm}$ at $25^{\circ} \mathrm{C}$ \\
\hline Water temperature & $\mathrm{X}$ & $\mathrm{X}$ & -- & ${ }^{\circ} \mathrm{C}$ \\
\hline \multicolumn{5}{|c|}{ Oxidizing agent } \\
\hline Perchlorate & $\mathrm{X}$ & $\mathrm{X}$ & $\mathrm{X}$ & $\mu \mathrm{g} / \mathrm{L} ; \mu \mathrm{g} / \mathrm{kg}$ \\
\hline \multicolumn{5}{|c|}{ Metals } \\
\hline Aluminum & $\mathrm{X}$ & $\mathrm{X}$ & $\mathrm{X}$ & $\mu \mathrm{g} / \mathrm{L} ; \mathrm{mg} / \mathrm{kg}$ \\
\hline Antimony & $\mathrm{X}$ & $\mathrm{X}$ & $\mathrm{X}$ & $\mu \mathrm{g} / \mathrm{L} ; \mathrm{mg} / \mathrm{kg}$ \\
\hline Arsenic & $\mathrm{X}$ & $\mathrm{X}$ & $\mathrm{X}$ & $\mu \mathrm{g} / \mathrm{L} ; \mathrm{mg} / \mathrm{kg}$ \\
\hline Barium & $\mathrm{X}$ & $X$ & $\mathrm{X}$ & $\mu \mathrm{g} / \mathrm{L} ; \mathrm{mg} / \mathrm{kg}$ \\
\hline Calcium & $\mathrm{X}$ & $\mathrm{X}$ & $\mathrm{X}$ & $\mu \mathrm{g} / \mathrm{L} ; \mathrm{mg} / \mathrm{kg}$ \\
\hline Copper & $\mathrm{X}$ & $\mathrm{X}$ & $\mathrm{X}$ & $\mu \mathrm{g} / \mathrm{L} ; \mathrm{mg} / \mathrm{kg}$ \\
\hline Lithium & $\mathrm{X}$ & $\mathrm{X}$ & $\mathrm{X}$ & $\mu \mathrm{g} / \mathrm{L} ; \mathrm{mg} / \mathrm{kg}$ \\
\hline Magnesium & $\mathrm{X}$ & $\mathrm{X}$ & $\mathrm{X}$ & $\mu \mathrm{g} / \mathrm{L} ; \mathrm{mg} / \mathrm{kg}$ \\
\hline Strontium & $\mathrm{X}$ & $\mathrm{X}$ & $\mathrm{X}$ & $\mu \mathrm{g} / \mathrm{L} ; \mathrm{mg} / \mathrm{kg}$ \\
\hline Titanium & $\mathrm{X}$ & $\mathrm{X}$ & $\mathrm{X}$ & $\mu \mathrm{g} / \mathrm{L} ; \mathrm{mg} / \mathrm{kg}$ \\
\hline Zinc & $\mathrm{X}$ & $\mathrm{X}$ & $\mathrm{X}$ & $\mu \mathrm{g} / \mathrm{L} ; \mathrm{mg} / \mathrm{kg}$ \\
\hline Berylium & -- & -- & $\mathrm{X}$ & $\mathrm{mg} / \mathrm{kg}$ \\
\hline Cadmium & -- & -- & $\mathrm{X}$ & $\mathrm{mg} / \mathrm{kg}$ \\
\hline Chromium & -- & -- & $\mathrm{X}$ & $\mathrm{mg} / \mathrm{kg}$ \\
\hline Cobalt & -- & -- & $\mathrm{X}$ & $\mathrm{mg} / \mathrm{kg}$ \\
\hline Iron & -- & -- & $X$ & $\mathrm{mg} / \mathrm{kg}$ \\
\hline Lead & -- & -- & $\mathrm{X}$ & $\mathrm{mg} / \mathrm{kg}$ \\
\hline Manganese & -- & -- & $\mathrm{X}$ & $\mathrm{mg} / \mathrm{kg}$ \\
\hline Molybdenum & -- & -- & $\mathrm{X}$ & $\mathrm{mg} / \mathrm{kg}$ \\
\hline Nickel & -- & -- & $\mathrm{X}$ & $\mathrm{mg} / \mathrm{kg}$ \\
\hline Potassium & -- & -- & $X$ & $\mathrm{mg} / \mathrm{kg}$ \\
\hline Selenium & -- & -- & $\mathrm{X}$ & $\mathrm{mg} / \mathrm{kg}$ \\
\hline Sodium & -- & -- & $\mathrm{X}$ & $\mathrm{mg} / \mathrm{kg}$ \\
\hline Thalium & -- & -- & $\mathrm{X}$ & $\mathrm{mg} / \mathrm{kg}$ \\
\hline Vanadium & -- & -- & $\mathrm{X}$ & $\mathrm{mg} / \mathrm{kg}$ \\
\hline
\end{tabular}

than $(<) 0.10 \mathrm{ft}^{3} / \mathrm{s}$. Powell and others $(1973)$ also measured the springflow, which was between 0.02 and $0.18 \mathrm{ft}^{3} / \mathrm{s}$ during 1960-67. As documented by Powell and others (1973) and Rahn (1990), springflow from this site originates from the same groundwater source that supplies the production wells.
The spring at site L-2 furnished the total water supply for Mount Rushmore National Memorial from 1927 until 1967 (Powell and others, 1973), when the 200-ft deep well at site L-3 was drilled and became the primary water supply for Mount Rushmore National Memorial through the present time (2016). A second production well (site L-4) was drilled to a depth of $500 \mathrm{ft}$ in 2010 (South Dakota Department of Environment and Natural Resources, 2016) and is located about $300 \mathrm{ft}$ northwest of the first well (site L-3). The Precambrian aquifer supplying the production wells is contained mainly in mica schist, and the rocks are extensively fractured and permeable (Powell and others, 1973). The hydrogeology of the springs in West Fork Lafferty Gulch near the two production wells is explained with a combination of several factors. Fractures exist in the mica schists, creating an aquifer from secondary porosity in rocks that otherwise would not contain enough porosity to provide a water supply. Powell and others (1973) described a pegmatite or granite sill extruding across the West Fork Lafferty Gulch draw, where the intrusive body acts as a groundwater dam. High-porosity saturated surficial deposits (colluvium, grus, talus, carving rubble) are located at the base of the granite outcrops, overlying the mica schists and granite (Rahn 1990). Well logs from the Mount Rushmore production wells indicate about $35 \mathrm{ft}$ of weathered surficial deposits on top of mica schists and granite. If not for the damming effect of the pegmatite or granite sill across the downstream valley of West Fork Lafferty Gulch, water would drain rapidly from the aquifer downgradient into the main Lafferty Gulch channel (Powell and others, 1973).

Sampling site L-5 is located on the main Lafferty Gulch channel downstream from the confluence with West Fork Lafferty Gulch, near the northern park boundary. Water from L-5 primarily consists of excess springflow from West Fork Lafferty Gulch (L-2 site) and treated wastewater from the upstream L-1 site. Downstream from site L-5, Lafferty Gulch flows north about $1 \mathrm{mi}$ until reaching its outlet into Battle Creek (fig. 1). Site L-6 is a 330-ft deep well that is located outside the eastern park boundary at a seasonal-use cabin and is completed in mica schists. This well was included in the study to provide additional insights into water quality from a well completed in geologic units similar to those of the Mount Rushmore production wells, but that are located downstream in the drainage basin.

To provide information about the effect of water treatment on the groundwater pumped from the West Fork Lafferty Gulch drainage, sampling site L-7 (fig. 1) was included. This site is a sampling point in the water distribution system for Mount Rushmore National Memorial after the raw well water has been through the water treatment plant process; thus, this sampling site represents finished water. The water treatment plant is designed primarily to remove arsenic and chlorinate the water supply but does not include a process for perchlorate removal (Rodney Hart, National Park Service, oral commun., 2014). Site L-8 is an ephemeral seep located on the talus slope just below the carving of President Lincoln on the eastern side of the memorial, in the headwaters of the main Lafferty 
Table 2. Sites within and adjacent to Mount Rushmore National Memorial where water and soil samples were collected, 2011-15.

[USGS, U.S. Geological Survey; S. Dak., South Dakota; SW, surface water; GW, groundwater; NM, National Memorial]

\begin{tabular}{|c|c|c|c|c|c|}
\hline Drainage basin & $\begin{array}{c}\text { Map } \\
\text { number } \\
\text { (fig. 1) }\end{array}$ & $\begin{array}{l}\text { USGS station } \\
\text { number }\end{array}$ & Station name & Site type & Description \\
\hline \multirow[t]{12}{*}{ Lafferty Gulch } & L-1 & 435250103270400 & $\begin{array}{l}\text { Lafferty Gulch below wastewater treatment plant at } \\
\text { Mount Rushmore, S. Dak. }\end{array}$ & Stream $(\mathrm{SW}) /$ soil & $\begin{array}{l}\text { Between wastewater treatment plant and West Fork } \\
\text { Lafferty Gulch. }\end{array}$ \\
\hline & L-2 & 435300103270800 & $\begin{array}{l}\text { West Fork Lafferty Gulch Creek above supply well at } \\
\text { Mount Rushmore, S. Dak. }\end{array}$ & Spring (SW)/soil & Upstream from production wells. \\
\hline & L-3 & 435300103265001 & 2S 6E 7CDD & Well (GW) & 200-foot-deep production well (Well \#1). \\
\hline & L-4 & 435302103270501 & 2S 6E 7CDD2 & Well (GW) & 500-foot-deep production well (Well \#2). \\
\hline & L-5 & 435302103265300 & Lafferty Gulch at Mount Rushmore, S. Dak. & Stream $(\mathrm{SW}) /$ soil & Downstream from West Fork Lafferty Gulch. \\
\hline & L-6 & 435312103264801 & 2S 6E 7DC & Well (GW) & $\begin{array}{l}\text { 330-foot-deep private well downstream from Mount } \\
\text { Rushmore NM. }\end{array}$ \\
\hline & L-7 & 435302103270201 & Mount Rushmore finished water near Keystone, S. Dak. & Well (GW) & Treated water supply for Mount Rushmore NM. \\
\hline & L-8 & 435245103273000 & Talus at Mount Rushmore Memorial, S. Dak. & Stream $(\mathrm{SW})$ & Downslope of Lincoln's head on monument slope. \\
\hline & L-9 & 435257103271701 & 2S 6E18B & Soil & Lafferty Gulch, 1,000 feet above wells. \\
\hline & L-10 & 435259103271401 & 2S 6E 7CD2 & Soil & Lafferty Gulch, 750 feet above wells. \\
\hline & L-11 & 435300103271001 & $2 \mathrm{~S} 6 \mathrm{E} 7 \mathrm{CD}$ & Soil & Lafferty Gulch, 400 feet above wells. \\
\hline & L-12 & 435245103273401 & 2S 5E13AA & Soil & $\begin{array}{l}\text { Top of Mount Rushmore NM, Hall of Records } \\
\text { Canyon. }\end{array}$ \\
\hline \multirow{3}{*}{$\begin{array}{l}\text { Unnamed tributary } \\
\text { to Grizzly Bear } \\
\text { Creek }\end{array}$} & G-1 & 435231103265101 & Spring near Grizzly Bear Creek at Mount Rushmore, S. Dak. & Spring (SW)/soil & Between parking lot and Grizzly Bear Creek. \\
\hline & G-2 & 435234103262600 & $\begin{array}{l}\text { Unnamed tributary above Grizzly Bear Creek at } \\
\text { Mount Rushmore, S. Dak. }\end{array}$ & Stream (SW) & About 200 feet upstream from Grizzly Bear Creek. \\
\hline & G-3 & 435242103261801 & 2S 6E18DDDB & Well (GW) & $\begin{array}{l}\text { 160-foot-deep well at Grizzly Bear Creek camp- } \\
\text { ground. }\end{array}$ \\
\hline \multirow[t]{2}{*}{ Starling Gulch } & S-1 & 435234103274500 & Starling Creek above marsh near Mount Rushmore, S. Dak & Stream $(\mathrm{SW}) /$ soil & $\begin{array}{l}\text { Upstream site on Starling Creek, } 400 \text { feet west of } \\
\text { profile turnout. }\end{array}$ \\
\hline & S-2 & 435214103273500 & Starling Creek at Mount Rushmore, S. Dak. & Stream $(\mathrm{SW})$ & Downstream from Starling Basin spring. \\
\hline \multirow[t]{2}{*}{ Pine Creek } & $\mathrm{P}-1$ & 435342103285801 & 2S 5E11ABDA2 & Well (GW) & 215-foot-deep well at Horsethief Lake campground. \\
\hline & $\mathrm{P}-2$ & 435327103290600 & Pine Creek above Horsethief Lake near Hill City, S. Dak. & Stream $(\mathrm{SW}) /$ soil & $\begin{array}{l}\text { Pine Creek above Horsethief Lake near camp- } \\
\text { ground. }\end{array}$ \\
\hline Iron Creek & $\mathrm{I}-1$ & 435044103241000 & Iron Creek above Lakota Lake near Keystone, S. Dak. & Stream $(\mathrm{SW}) /$ soil & Southwest of Lakota Lake near Highway 16A. \\
\hline
\end{tabular}


Gulch drainage. This seep is not connected to the aquifers in other parts of Lafferty Gulch, but rather produces water that is stored in the carving rubble and other surficial deposits following snowmelt and rainfall events. Site L-8 is the closest water sampling site in proximity to the fireworks launch area in the Hall of Records Canyon, directly behind the memorial. Sites L-9, L-10, L-11, and L-12 (fig. 1) are soil sampling locations in targeted areas suspected of collecting the largest amount of firework debris. Site L-12 is located within the Hall of Records Canyon, where a shallow layer of soil and weathered rock overlies the large granite outcrop. Sites L-9, L-10, and L-11 are located in the West Fork Lafferty Gulch drainage, in the recharge zone identified by Rahn (1990), upstream from the production wells (sites L-3 and L-4).

Located outside of Lafferty Gulch drainage basin, site G-1 is a spring located east of the parking lot area along an unnamed tributary to Grizzly Bear Creek. The geology of this spring is similar to that of site L-2 (upstream from the production wells in West Fork Lafferty Gulch), where a pegmatite or granite sill blocks the downstream flow of groundwater and builds sufficient hydraulic head for surficial springflow. Site G-2 is a stream site downstream (east) from the G-1 spring, located just upstream from the Grizzly Bear Campground. In addition to receiving springflow, site G-2 also receives runoff during precipitation events from the Mount Rushmore parking lot. Site G-3 is a 160-ft deep well at the Grizzly Bear Campground, constructed in 1978 (Brian Beam, U.S. Forest Service, written commun., 2015).

Two sampling sites were located in the Starling Gulch drainage basin, along the western flank of Mount Rushmore National Memorial. The geology in the Starling Gulch drainage basin predominantly is schist mantled by alluvium along the main drainage valley and is surrounded by high hills of granite and schist (Redden and DeWitt, 2008). The upper site, $\mathrm{S}-1$, is located about $400 \mathrm{ft}$ west of highway 244 . The lower site, S-2, is located downstream from two tributaries that drain the western side of the Mount Rushmore parking lot and visitor center. Downstream from site S-2, Starling Creek flows about 0.4 mi until its confluence with Grizzly Bear Creek. During the study, flow in Starling Creek was ephemeral during dry periods in the summer but had a sustained flow at both sites during wetter periods in the late spring and early summer. Groundwater in the alluvium in the valley likely fed the stream until it was depleted in the late summer months, after which time the only flow observed was during runoff events.

One groundwater site and two surface-water sites were located outside of the Mount Rushmore National Memorial boundary to provide a comparison of water quality within the park boundary to reference locations in similar geologic settings. Site P-1 is a 215-ft deep well located at Horsethief Lake Campground, about 1 mi northwest of the park boundary in the Pine Creek drainage basin. This well is completed in predominantly mica schist and quartz, with some slate in the bottom $30 \mathrm{ft}$ (U.S. Forest Service, written commun., 2014). Site P-2 is on Pine Creek upstream from Horsethief Lake, which is shallow perennial stream that feeds Horsethief Lake. Similarly, site I-1 is on Iron Creek upstream from Lakota
Lake, about $2.5 \mathrm{mi}$ from the southeast park boundary. Both the Pine Creek and Iron Creek drainages have similar topography, surficial geology, and climate, which allows for comparison of water quality from these sites to those within Mount Rushmore National Memorial.

\section{Collection, Processing, and Analyses of Water Samples}

Field water-quality properties that were measured during each sampling event included dissolved oxygen (DO), $\mathrm{pH}$, specific conductance (SC), and water temperature. Physical properties are critical to the understanding of the viability and vulnerability of environmental waters and are considered important variables in determining the aqueous chemistry of a system. Physical properties are important indicators of the ability of a waterbody to sustain life and can be used to track changes in a system. Groundwater-level fluctuations due to aquifer storage changes involve either the addition or extraction of water from the aquifer both through natural means and human involvement, and can cause variation in field properties. Water temperature measurements aid in the estimation of chemical reaction rates and equilibria, biological activity, and fluid properties.

Potential sources for metals in water resources within Mount Rushmore National Memorial include the natural occurrence of the chemicals in granite and schists that constitute the lithology of the area; past firework displays at the memorial; or other anthropogenic factors related to the construction, infrastructure, and vehicle traffic. The variety of potential sources makes it difficult to attribute high metal concentrations to a specific source.

Chlorofluorocarbons (CFCs) were used to estimate age dates of groundwater samples collected at Mount Rushmore National Memorial in 2013 and can provide important insights on what portion of the water was recharged in recent years (after firework displays ceased in 2009). The principle of groundwater age dating relies on the measure of a trace constituent existing in the atmosphere for a known period of time and an approximate concentration. The CFCs are stable, synthetic, halogenated alkanes developed in the early 1930s as safe alternatives to ammonia and sulphur dioxide in refrigeration (U.S. Geological Survey, 2015). Production of CFC-12 (dichlorodifluoromethane, $\mathrm{CF}_{2} \mathrm{Cl}_{2}$ ) began in 1931 and was followed by production of $\mathrm{CFC}-11$ (trichlorofluoromethane, $\mathrm{CFCl}_{3}$ ) in 1936. Many other CFC compounds have since been produced, most notably CFC-113 (trichlorotrifluoroethane, $\mathrm{C}_{2} \mathrm{~F}_{3} \mathrm{Cl}_{3}$ ). Based on the assumption that the precipitation that recharged the aquifer reached equilibrium with these atmospheric substances, calculation of an "apparent age" of the water is possible. In the simplest model, it is assumed that the water travels in "piston flow" (that is, the water does not mix with other sources until it is pumped). In most shallow unconfined systems, however, mixing of older groundwater with recent recharge is common, so the apparent age represents a mean of the actual recharge ages (Hinkle and Snyder, 1997). 
U.S. Geological Survey protocols and procedures were used for the collection of groundwater and surface-water samples (U.S. Geological Survey, variously dated) for the measurement of field properties and concentrations of perchlorate and selected metals. Field properties including DO, $\mathrm{pH}, \mathrm{SC}$, and water temperature were measured with each sample collection. The CFC samples were collected at well sites for estimation of groundwater age, or the apparent date at which the water was recharged into the aquifer. For well sites, existing water spigots on the distribution line were used for sample collection. A brass hose fitting was used to connect the spigot to Teflon ${ }^{\circledR}$ sample tubing. During most sampling visits, the wells had been pumped for several hours prior to arrival, ensuring that groundwater sampled was representative of the aquifer. If the well had not been purged recently, water was pumped out of the well through the plumbing system for several minutes prior to sample collection. Field properties were checked for stability in at least three consecutive 5-minute interval readings to ensure water-quality conditions were no longer changing due to stagnant water in the well bore. Stream and spring samples were collected using a single-point dip technique from the center of flow. Most stream sites had flow widths $<2 \mathrm{ft}$ and depths $<1 \mathrm{ft}$ in a well-mixed channel, so isokinetic, depth-integrating methods were not warranted.

Water samples were analyzed for perchlorate using EPA Method 6860 by Test America Laboratories, Inc., in Arvada, Colorado, at a reporting level of $0.04 \mu \mathrm{g} / \mathrm{L}$ using ion chromatography/electrospray ionization/mass spectrometry (U.S. Environmental Protection Agency, 2007). Laboratory quality-control methods included (1) control samples that evaluate the ability of the laboratory to accurately identify and quantitate a target compound in reference matrix at a known concentration; and (2) laboratory control sample duplicates, which also check laboratory preparation and analytical precision. Groundwater and surface-water samples collected for measurement of selected metals were analyzed using inductively coupled plasma mass spectrometry by the USGS National Water Quality Laboratory in Lakewood, Colo., using methods of Garbarino and Struzeski (1998).

The CFC samples were analyzed by the USGS Reston Chlorofluorocarbon Laboratory, in Reston, Virginia (U.S. Geological Survey, 2015). Concentrations of CFCs were determined in the laboratory using a purge and trap gas chromatography procedure with an electron capture detector. Gas and water blanks were used to determine that the instruments were free of contamination.

\section{Collection, Processing, and Analyses of Soil Samples}

Soil samples were collected during one sampling visit at locations in proximity to surface-water sampling sites (about $50 \mathrm{ft}$ away from the active stream channels) and also at four sites (L-12, L-9, L-10, and L-11) in a line from the Hall of Records Canyon towards the production wells L-3 and L-4 in West Fork Lafferty Gulch (fig. 1). Samples were collected in accordance with the Incremental Sampling Methodology (Interstate Technology and Regulatory Council, 2012) to obtain analyte concentrations representative of the drainage area. The sampling area consisted of a 5-by-6-ft grid (fig. 2) that was partitioned into 30 individual square-foot units. Soil borings of 1-in. diameter

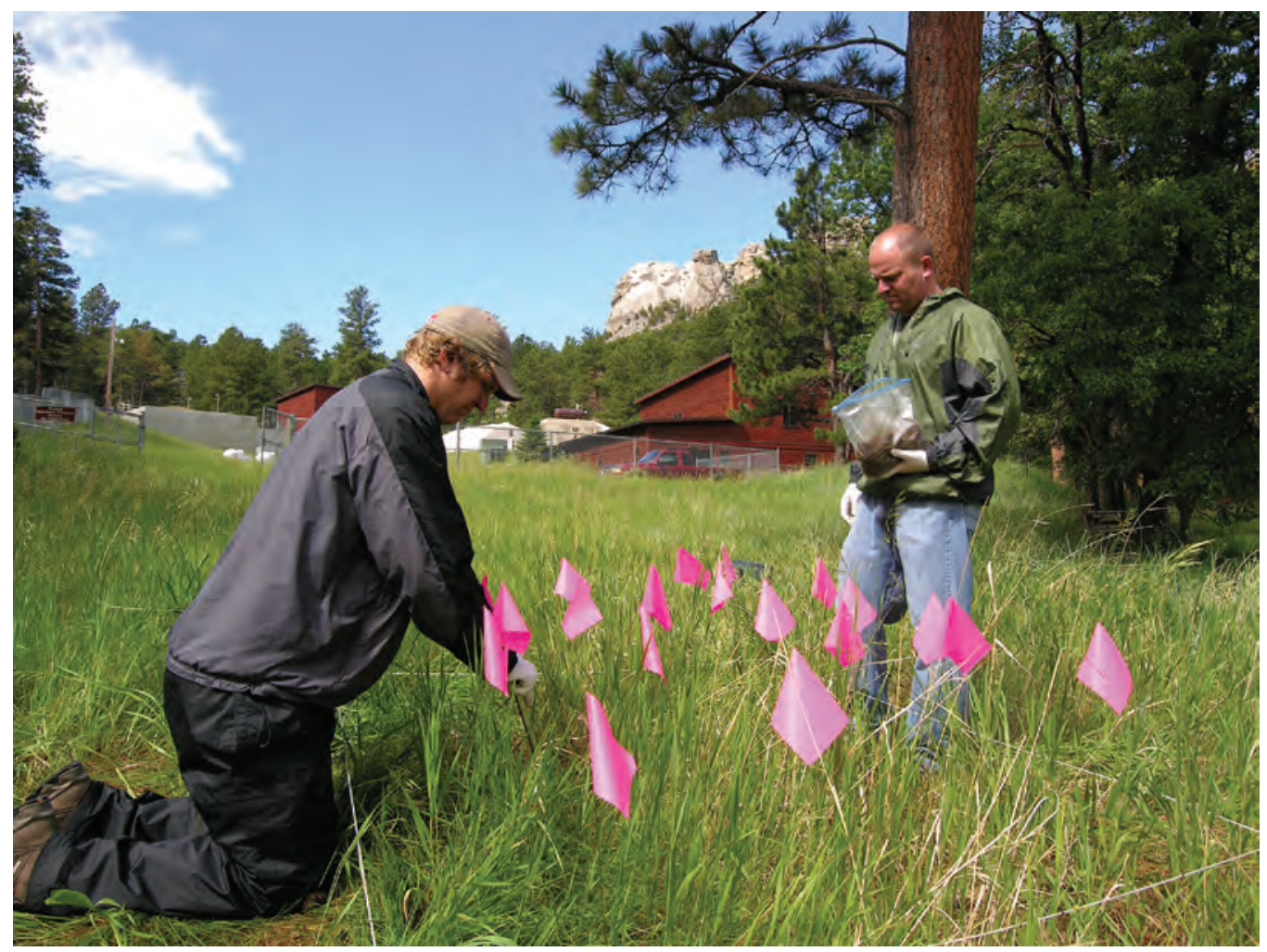
were collected at a depth of about $8 \mathrm{in}$. within the centroid of each squarefoot unit and integrated to represent one sample. The single sample (composited from the 30 subsamples) was air dried. Large nonrepresentative pieces that would not pass through the sieve (for example, rocks and twigs) were manually removed. Other extraneous material was removed by sieving. A mortar and pestle or sieve shaker was used to break up soil agglomerates during the sieving process.

Figure 2. Collection of composite soil samples, Mount Rushmore National Memorial. 
After completion of preparation, samples were shipped to Test America Laboratories, Inc., in Arvada, Colo., for analyses of perchlorate and selected metals by inductively coupled plasma-atomic emission spectrometry using EPA method 6010B (U.S. Environmental Protection Agency, 1996).

\section{Quality Assurance and Quality Control}

A quality-assurance/quality-control approach was used to identify possible cases of random or systematic errors in the field sampling, shipping, and laboratory analyses. Qualityassurance measures include using standard procedures for streamflow measurements and water-quality sample collection according to the USGS National Field Manual (U.S. Geological Survey, variously dated). For water-quality samples, fieldequipment blank and sequential replicate samples were used to determine the potential for sample contamination (Mueller and others, 2015).

Field-equipment blank samples for water samples were collected at sites by passing analyte-free water through the collection and processing equipment before it was used for the environmental samples and by using procedures identical to those used to collect and process the environmental samples. Constituent concentrations less than the minimum reporting level (MRL) in field-equipment blank samples indicate that the overall process of sample collection, processing, and laboratory analysis was free of substantial contamination. The MRL is the lowest measured concentration of a constituent that may be reliably reported from the use of a given analytical method (Timme, 1995). Sporadic, infrequent detections at concentrations near the MRL probably represent contamination from sample collection, processing, or shipping that is not likely to cause bias in the study results. Consistent detections in the field-equipment blank samples at concentrations within the range of concentrations in the environmental samples indicate that environmental concentrations need to be qualified or omitted from study results (Mueller and others, 2015). Fieldequipment blank samples were collected with nine samples for analyses of perchlorate and metals during 2012-14 (table 3). All perchlorate concentrations in blank samples were less than the MRL (ranging from 0.0088 to $0.20 \mu \mathrm{g} / \mathrm{L}$ ). Four different metals were detected in three field-equipment blank samples, all from the groundwater site L-3. Two of the metals detected in blank samples, copper and zinc, can be explained by the use of brass fittings to connect onto distribution pipes or spigots (brass is an alloy of zinc and copper). A blank sample collected on December 9, 2014, was especially high in zinc and copper, with concentrations greater than 10 times the mean environmental concentration at the site. Other groundwater well sites had samples with anomalously high copper or zinc concentrations in at least one sample, likely caused by the use of brass fittings. For example, a sample from L-7 on December 9, 2014, had a zinc concentration of $153 \mu \mathrm{g} / \mathrm{L}$ compared to a maximum concentration of $13 \mu \mathrm{g} / \mathrm{L}$ in five other samples from the same site. For this reason, zinc and copper results from all well sites (sites L-3, L-4, L-6, L-7, G-3, and P-1) are considered to be unreliable due to contamination problems with brass plumbing fittings. Similar sampling materials were used at all well sites, and thus the brass contamination issue is likely similar for the water-quality data from these five sites. Concentrations of zinc and copper for well sites were censored (removed) in the dataset for this study. Calcium was detected in two blank samples at a maximum concentration of 0.025 milligram per liter $(\mathrm{mg} / \mathrm{L})$; whereas, the mean concentration in environmental samples from the same site was $10.8 \mathrm{mg} / \mathrm{L}$. Barium was detected in two blank samples at a mean concentration of $0.26 \mathrm{mg} / \mathrm{L}$, which is near the MRL of $0.25 \mathrm{mg} / \mathrm{L}$, whereas the mean concentration in environmental samples from the same site was $17.7 \mathrm{mg} / \mathrm{L}$. For calcium and barium, the presence of small concentrations relative to its environmental concentration and their less frequent occurrence are not likely to cause bias in the dataset, and thus calcium and barium concentrations were not censored.

Precision of analytical results for field replicate samples may be affected by numerous sources of potential variability in field and laboratory processes, including sample collection, sample processing and handling, and laboratory preparation and analysis. Analyses of field replicate samples, therefore, can indicate the reproducibility of environmental data and provide information on the variability associated with sample collection and analysis (Mueller and others, 2015). Field replicate samples were analyzed for perchlorate and metals in 10 water samples (table 3), and two replicate soil samples were collected (table 4). Relative percent difference (RPD) was calculated as the difference in concentration between the environmental sample and replicate sample divided by mean concentration multiplied by 100 for each environmental and replicate pair. The mean RPD for all environmental and replicate pairs for perchlorate in groundwater and surface water was about 2.8 percent, indicating satisfactory data quality control for this constituent. In groundwater samples, poor RPDs were noted for copper and zinc (mean RPD of 29 and 17 percent, respectively), which can again be attributed to the use of brass plumbing fittings causing the contamination issue with groundwater samples and provides further justification for censoring these two constituents in environmental samples. Aluminum also had relatively high RPD values in groundwater samples, averaging 11 percent. Surface-water samples did not have a similar contamination issue, because the mean RPDs for all metals in surface-water samples were $<7$ percent, indicating satisfactory data quality control.

Two replicate soil samples were collected, which had RPDs of 5.3 and 42 percent for perchlorate (table 4). The replicate soil sample with a relatively large RPD of 42 percent was primarily the result of a small difference in low concentrations; the environmental and replicate sample had perchlorate concentrations of 0.29 and $0.19 \mu \mathrm{g} / \mathrm{L}$, respectively. All other metals had a mean RPD of 2.5 percent in the soil sample from the S-1 site on 6/20/2012 and a mean RPD of 9.9 percent in the soil sample from the P-2 site on 6/6/2013. These RPD results from soil samples indicate satisfactory data quality 
Table 3. Water-quality information for groundwater and surface-water field blank and replicate samples within and adjacent to Mount Rushmore National Memorial, 2012-15.

[USGS, U.S. Geological Survey; mg/L, milligrams per liter; $\mu \mathrm{g} / \mathrm{L}$, micrograms per liter; <, less than]

\begin{tabular}{|c|c|c|c|c|c|c|c|c|c|c|c|c|c|c|}
\hline $\begin{array}{c}\text { USGS station } \\
\text { number }\end{array}$ & $\begin{array}{c}\text { Map } \\
\text { number } \\
\text { (fig. 1) }\end{array}$ & Date & Time & $\begin{array}{c}\text { Calcium } \\
\text { (mg/L) }\end{array}$ & $\begin{array}{l}\text { Magnesium } \\
\quad(\mathrm{mg} / \mathrm{L})\end{array}$ & $\begin{array}{c}\text { Aluminum } \\
(\mathrm{mg} / \mathrm{L})\end{array}$ & $\begin{array}{c}\text { Barium } \\
\text { ( } \mu \mathrm{g} / \mathrm{L})\end{array}$ & $\begin{array}{l}\text { Copper } \\
(\mu \mathrm{g} / \mathrm{L})\end{array}$ & $\begin{array}{c}\text { Lithium } \\
(\mu \mathrm{g} / \mathrm{L})\end{array}$ & $\begin{array}{c}\text { Strontium } \\
(\mu \mathrm{g} / \mathrm{L})\end{array}$ & $\begin{array}{l}\text { Zinc } \\
(\mu \mathrm{g} / \mathrm{L})\end{array}$ & $\begin{array}{c}\text { Antimony } \\
(\mu \mathrm{g} / \mathrm{L})\end{array}$ & $\begin{array}{c}\text { Arsenic } \\
(\mu \mathrm{g} / \mathrm{L})\end{array}$ & $\begin{array}{c}\text { Perchlorate } \\
\text { ( } \mu \mathrm{g} / \mathrm{L})\end{array}$ \\
\hline \multicolumn{15}{|c|}{ Field blank water samples } \\
\hline 435250103270400 & L-1 & $07 / 16 / 2014$ & 1040 & $<0.021$ & $<0.010$ & $<3.8$ & $<0.25$ & $<0.80$ & $<0.22$ & $<0.80$ & $<2.0$ & $<0.18$ & $<0.28$ & $<0.20$ \\
\hline 435300103270800 & L-2 & $06 / 18 / 2014$ & 915 & $<0.021$ & $<0.010$ & $<3.8$ & $<0.25$ & $<0.80$ & $<0.22$ & $<0.80$ & $<2.0$ & $<0.18$ & $<0.28$ & $<0.20$ \\
\hline 435300103265001 & L-3 & $07 / 10 / 2012$ & 1045 & $<0.021$ & $<0.007$ & $<3.8$ & $<0.06$ & $<0.70$ & $<0.15$ & $<0.80$ & $<3.0$ & $<0.18$ & $<0.28$ & $<0.01$ \\
\hline 435300103265001 & L-3 & $05 / 07 / 2013$ & 930 & $<0.021$ & $<0.007$ & $<3.8$ & 0.14 & 0.75 & $<0.15$ & $<0.80$ & 7.4 & $<0.18$ & $<0.28$ & $<0.0088$ \\
\hline 435300103265001 & L-3 & 08/06/2013 & 1005 & $<0.021$ & $<0.007$ & $<3.8$ & $<0.06$ & 2.4 & $<0.15$ & $<0.80$ & 24 & $<0.18$ & $<0.28$ & $<0.0088$ \\
\hline 435300103265001 & L-3 & $12 / 09 / 2014$ & 1005 & 0.025 & $<0.010$ & $<3.8$ & 0.37 & 233 & $<0.22$ & $<0.80$ & 189 & $<0.18$ & $<0.20$ & $<0.0190$ \\
\hline 435302103270501 & L-4 & 05/01/2012 & 1300 & 0.023 & $<0.007$ & $<3.8$ & $<0.06$ & $<0.70$ & $<0.15$ & $<0.80$ & $<3.0$ & $<0.18$ & $<0.28$ & $<0.01$ \\
\hline 435302103270501 & L-4 & $08 / 26 / 2014$ & 1005 & $<0.021$ & $<0.010$ & $<3.8$ & $<0.25$ & $<0.80$ & $<0.22$ & $<0.80$ & $<2.0$ & $<0.18$ & $<0.28$ & $<0.20$ \\
\hline 435242103261801 & G-3 & $06 / 18 / 2014$ & 1005 & $<0.021$ & $<0.010$ & $<3.8$ & $<0.25$ & $<0.80$ & $<0.22$ & $<0.80$ & $<2.0$ & $<0.18$ & $<0.28$ & $<0.20$ \\
\hline \multicolumn{15}{|c|}{ Replicate water sample pairs } \\
\hline 435300103270800 & L-2 & $06 / 05 / 2012$ & 1142 & 6.72 & 1.78 & 104 & 13.1 & $<0.70$ & 20.7 & 34 & $<3.0$ & $<0.18$ & 14.9 & 52 \\
\hline 435300103270800 & L-2 & $06 / 05 / 2012$ & 1140 & 6.98 & 1.83 & 113 & 13.3 & $<0.70$ & 20.3 & 33.9 & $<3.0$ & $<0.18$ & 14.9 & 52 \\
\hline 435300103270800 & L-2 & $07 / 09 / 2013$ & 1055 & 7.05 & 1.82 & 133 & 14.2 & $<0.70$ & 21.3 & 35.7 & $<3.0$ & $<0.18$ & 16 & 46 \\
\hline 435300103270800 & L-2 & $07 / 09 / 2013$ & 1050 & 6.95 & 1.81 & 118 & 14.2 & $<0.70$ & 21.2 & 35.6 & $<3.0$ & $<0.18$ & 15.7 & 46 \\
\hline 435300103265001 & L-3 & $05 / 15 / 2014$ & 1000 & 10.4 & 2.71 & 98.9 & 16.7 & 2.8 & 27.5 & 49.7 & 5.9 & $<0.18$ & 13.9 & 32 \\
\hline 435300103265001 & L-3 & $05 / 15 / 2014$ & 955 & 10.3 & 2.71 & 98.2 & 16.6 & 17 & 27.2 & 50 & 12.4 & $<0.18$ & 14.2 & 31 \\
\hline 435302103270501 & L-4 & 08/14/2012 & 835 & 9.09 & 2.34 & 40.6 & 8.63 & 4.4 & 29.9 & 46 & 4.7 & $<0.18$ & 27.3 & 2.2 \\
\hline 435302103270501 & L-4 & $08 / 14 / 2012$ & 830 & 8.99 & 2.31 & 41.2 & 8.72 & 4.5 & 30.1 & 46.1 & 4.8 & $<0.18$ & 27.5 & 2.1 \\
\hline 435302103270501 & L-4 & $06 / 04 / 2013$ & 1145 & 9.8 & 2.68 & 130 & 11.3 & 3.4 & 30.7 & 49.4 & 9.8 & $<0.18$ & 25.4 & 15 \\
\hline 435302103270501 & L-4 & $06 / 04 / 2013$ & 1142 & 9.94 & 2.72 & 116 & 11.1 & 5.4 & 30.4 & 49.1 & 10.8 & $<0.18$ & 24.9 & 14 \\
\hline 435312103264801 & L-6 & 05/19/2014 & 1230 & 16.7 & 4.91 & 197 & 30.3 & 17.3 & 69.6 & 82.2 & 14 & $<0.18$ & 70.2 & $<0.20$ \\
\hline 435312103264801 & L-6 & 05/19/2014 & 1225 & 16.5 & 4.85 & 171 & 30.2 & 16.3 & 68.6 & 81.3 & 13.7 & $<0.18$ & 69.7 & $<0.20$ \\
\hline 435302103270201 & $\mathrm{~L}-7$ & $08 / 06 / 2013$ & 1105 & 11.3 & 2.72 & 5.9 & 15.8 & 8.1 & 30.8 & 56.7 & 9.9 & $<0.18$ & 1.4 & 17 \\
\hline 435302103270201 & L-7 & 08/06/2013 & 1100 & 11.5 & 2.78 & 6.5 & 15.7 & 8.2 & 30.2 & 57.3 & 10 & $<0.18$ & 1.3 & 16 \\
\hline 435302103270201 & L-7 & $02 / 18 / 2015$ & 955 & 10.8 & 2.58 & 5.1 & 15.5 & 3.5 & 26.7 & 56.5 & 10.4 & $<0.18$ & 2.7 & 19 \\
\hline 435302103270201 & L-7 & $02 / 18 / 2015$ & 950 & 11.4 & 2.65 & 5.1 & 15.5 & 3.5 & 26.6 & 56.9 & 10.6 & $<0.18$ & 2.7 & 20 \\
\hline 435234103262600 & G-2 & 08/26/2014 & 1005 & 50.6 & 11.4 & 25.2 & 100 & $<0.80$ & 40.7 & 200 & $<2.0$ & $<0.18$ & 2.3 & $<0.20$ \\
\hline 435234103262600 & G-2 & $08 / 26 / 2014$ & 1000 & 50.8 & 11.5 & 25 & 101 & $<0.80$ & 40.2 & 200 & $<2.0$ & $<0.18$ & 2.2 & $<0.20$ \\
\hline 435342103285801 & $\mathrm{P}-1$ & $06 / 06 / 2013$ & 1505 & 19.8 & 4.95 & 58.1 & 39.2 & 8.3 & 93.8 & 97.7 & 54.6 & $<0.18$ & 120 & 0.058 \\
\hline 435342103285801 & $\mathrm{P}-1$ & $06 / 06 / 2013$ & 1500 & 20.2 & 5.08 & 89.6 & 38.1 & 8.9 & 96.6 & 98.6 & 73.1 & $<0.18$ & 83.8 & 0.057 \\
\hline \multicolumn{15}{|c|}{ Relative percent differences in water samples } \\
\hline 435300103270800 & L-2 & $06 / 05 / 2012$ & 1140 & 3.8 & 2.8 & 8.3 & 1.5 & 0.0 & 2.0 & 0.3 & 0.0 & 0.0 & 0.0 & 0.0 \\
\hline 435300103270800 & L-2 & $07 / 09 / 2013$ & 1050 & 1.4 & 0.6 & 12 & 0.0 & 0.0 & 0.5 & 0.3 & 0.0 & 0.0 & 1.9 & 0.0 \\
\hline 435300103265001 & L-3 & $05 / 15 / 2014$ & 955 & 1.0 & 0.0 & 0.7 & 0.6 & 143 & 1.1 & 0.6 & 71 & 0.0 & 2.1 & 3.2 \\
\hline 435302103270501 & L-4 & 08/14/2012 & 830 & 1.1 & 1.3 & 1.5 & 1.0 & 2.2 & 0.7 & 0.2 & 2.1 & 0.0 & 0.7 & 4.7 \\
\hline 435302103270501 & L-4 & $06 / 04 / 2013$ & 1142 & 1.4 & 1.5 & 11 & 1.8 & 45 & 1.0 & 0.6 & 9.7 & 0.0 & 2.0 & 6.9 \\
\hline 435312103264801 & L-6 & 05/19/2014 & 1225 & 1.2 & 1.2 & 14 & 0.3 & 6.0 & 1.4 & 1.1 & 2.2 & 0.0 & 0.7 & 0.0 \\
\hline 435302103270201 & L-7 & $08 / 06 / 2013$ & 1100 & 1.8 & 2.2 & 9.7 & 0.6 & 1.2 & 2.0 & 1.1 & 1.0 & 0.0 & 7.4 & 6.1 \\
\hline 435302103270201 & L-7 & $02 / 18 / 2015$ & 950 & 5.4 & 2.7 & 0.0 & 0.0 & 0.0 & 0.4 & 0.7 & 1.9 & 0.0 & 0.0 & 5.1 \\
\hline 435234103262600 & G-2 & $08 / 26 / 2014$ & 1000 & 0.4 & 0.9 & 0.8 & 1.0 & 0.0 & 1.2 & 0.0 & 0.0 & 0.0 & 4.4 & 0.0 \\
\hline 435342103285801 & $\mathrm{P}-1$ & $06 / 06 / 2013$ & 1500 & 2.0 & 2.6 & 43 & 2.8 & 7.0 & 2.9 & 0.9 & 29 & 0.0 & 36 & 1.7 \\
\hline
\end{tabular}


control and repeatability of the sample collection method. Soil concentrations reported with an "E" preceding the value in table 4 either (1) are below the MRL but greater than the established method detection limit, or (2) exceed the upper calibration range of the instrument. There is greater uncertainty associated with these results and data should be considered as estimated.

\section{Perchlorate and Metal Occurrence at Mount Rushmore National Memorial}

Groundwater and surface-water samples were collected at sites within Mount Rushmore National Memorial and adjacent basins during the summer months of May through August in 2011-14. Two groundwater samples were collected in the winter months of December 2014 and February 2015. The following sections describe the results from the 106 water samples collected from 20 sites, and 11 soil samples collected from 11 sites. Complete results for water and soil samples are presented in the appendix, and statistical summaries for each site are presented in table 5. Water-quality data also are available from the USGS National Water Information System (U.S. Geological Survey, 2016b) by using the USGS station numbers provided in table 2. Reference sites (P-1, P-2, and I-1; fig. 1) located in watersheds adjacent to the park unit were considered to be distant from the trajectory of fireworks (launched from Hall of Records Canyon, fig. 1). Analytical results from samples collected at reference sites may aid in defining background levels of perchlorate and metals. Concentrations of perchlorate and metals within the launch area may be indicative of point-source contamination. The natural occurrence of the metals in the igneous and metamorphic rocks of Mount Rushmore National Memorial also are a consideration when assessing constituent concentrations.

\section{Field Properties of Water Samples}

Aerobic conditions (presence of DO) are characteristic of surface water and groundwater within Mount Rushmore National Memorial. Measurements of DO concentrations within the Lafferty Gulch drainage basin ranged from 7.0 to $12.1 \mathrm{mg} / \mathrm{L}$ for surface water and from 2.0 to $6.4 \mathrm{mg} / \mathrm{L}$ for groundwater (table 5). Median DO concentrations in surface water in the Lafferty Gulch drainage basin ranged from 8.0 to $11.6 \mathrm{mg} / \mathrm{L}$. The median DO concentration in water from production well L-3 was $3.6 \mathrm{mg} / \mathrm{L}$, whereas water from the deeper production well L-4 had a median DO concentration of $2.8 \mathrm{mg} / \mathrm{L}$. The median DO concentration in treated (finished) groundwater (site L-7) was $9.2 \mathrm{mg} / \mathrm{L}$, which is greater than the untreated (raw) groundwater because of the treatment process. In the unnamed tributary to Grizzly Bear Creek and Starling Gulch, measurements of DO concentrations ranged from 3.3 to $11.5 \mathrm{mg} / \mathrm{L}$ at four surface-water sites $(\mathrm{G}-1, \mathrm{G}-2$,
S-1, and S-2), with median concentrations ranging from 6.3 to $10.2 \mathrm{mg} / \mathrm{L}$ at each site. At surface-water sites outside of the Mount Rushmore National Memorial boundary, median DO concentrations were $9.0 \mathrm{mg} / \mathrm{L}$ at Pine Creek and Iron Creek (sites P-2 and I-1, respectively), similar to those within the park boundary. Concentrations of DO in groundwater sites outside of the park boundary (sites G-3 and P-1) ranged from 0.5 to $7.8 \mathrm{mg} / \mathrm{L}$.

Most natural waters are slightly basic (approximately at a $\mathrm{pH}$ of 8); however, water from recent precipitation can be slightly acidic (approximately at a $\mathrm{pH}$ of 6 ; Hem, 1985). The median $\mathrm{pH}$ of groundwater ranged from 6.1 to 7.1 for the six well sites sampled. The median $\mathrm{pH}$ for surface water ranged from 5.8 to 7.9 for all sites (table 5), within the typical range of most natural waters. The relatively low $\mathrm{pH}$ at site L-8 (median of 5.8) was similar to the $\mathrm{pH}$ of unpolluted rainfall (about 5.6; Casiday and Frey, 1998), indicating the water source was generally pristine and not in contact with other geological materials long enough to alter the $\mathrm{pH}$.

Specific conductance is a measure of the ability of water to conduct an electrical current and is typically correlated positively with the concentration of dissolved constituents (Hem, 1985). At groundwater sites, SC values generally were very consistent throughout the study period, but surface-water sites had more variability in SC values depending on the runoff conditions prior to the sampling time. At surface-water sites, median $\mathrm{SC}$ values ranged from 39 microsiemens per centimeter at 25 degrees Celsius $(\mu \mathrm{S} / \mathrm{cm})$ at site L-8 to $612 \mu \mathrm{S} / \mathrm{cm}$ at site L-1. As previously described, site L- 8 is an ephemeral seep that produces water that is stored in the carving rubble and other surficial deposits following snowmelt and rainfall events; the predominantly recent precipitation sampled at this site likely contributed to the low $\mathrm{SC}$ values. In contrast, the water at site L-1 is predominantly treated wastewater, which results in greater dissolved solids and greater $\mathrm{SC}$ values. The groundwater sites within Lafferty Gulch basin (L-3, L-4, L-6, and L-7) were consistent, ranging from 101 to $195 \mu \mathrm{S} / \mathrm{cm}$. Groundwater from the basins outside of Lafferty Gulch (sites G-3 and P-1) had higher SC, ranging from 208 to $435 \mu \mathrm{S} / \mathrm{cm}$. Surface-water sites outside of the Mt. Rushmore National Memorial boundary (sites P-2 and I-1) had relatively low SC values, with median values of 56 and $79 \mu \mathrm{S} / \mathrm{cm}$, respectively. The median SC at site L-2 was $95 \mu \mathrm{S} / \mathrm{cm}$, whereas the remaining surface-water sites within the park boundary (drainage basins for Lafferty Gulch, unnamed tributary to Grizzly Bear Creek, and Starling Gulch) had median SC values ranging from 277 to $612 \mu \mathrm{S} / \mathrm{cm}$.

The water temperature for groundwater and surface water generally increased during the months of May through August, coinciding with increasing air temperatures during the summer. Temperatures ranged from 7.0 to 14.8 degrees Celsius $\left({ }^{\circ} \mathrm{C}\right.$ ) in groundwater (excluding treated groundwater at site L-7) and from 3.6 to $19.9^{\circ} \mathrm{C}$ for surface water. The median water temperature for the 500 -ft deep production well (site $\mathrm{L}-4 ; 11.2{ }^{\circ} \mathrm{C}$ ) was greater than the median temperature for the 200-ft deep production well (site L-3; $10.4^{\circ} \mathrm{C}$ ). 
Table 4. Perchlorate and selected metal concentrations and relative percent differences in replicate soil sample pairs collected within and adjacent to Mount Rushmore National Memorial, 2012-13.

[USGS, U.S. Geological Survey; mg/kg, milligrams per kilogram; $\mu \mathrm{g} / \mathrm{kg}$, micrograms per kilogram; E, estimated concentration'; <, less than]

\begin{tabular}{|c|c|c|c|c|c|c|c|c|c|c|c|c|c|c|c|c|}
\hline $\begin{array}{l}\text { USGS station } \\
\text { number }\end{array}$ & $\begin{array}{c}\text { Map } \\
\text { number } \\
\text { (fig. 1) }\end{array}$ & Date & $\begin{array}{c}\text { Aluminum } \\
\text { (mg/kg) }\end{array}$ & $\begin{array}{c}\text { Antimony } \\
\text { (mg/kg) }\end{array}$ & $\begin{array}{l}\text { Arsenic } \\
(\mathrm{mg} / \mathrm{kg})\end{array}$ & $\begin{array}{l}\text { Barium } \\
\text { (mg/kg) }\end{array}$ & $\begin{array}{c}\text { Beryllium } \\
\text { (mg/kg) }\end{array}$ & $\begin{array}{l}\text { Cadmium } \\
\text { (mg/kg) }\end{array}$ & $\begin{array}{l}\text { Calcium } \\
\text { (mg/kg) }\end{array}$ & $\begin{array}{l}\text { Chromium } \\
\text { (mg/kg) }\end{array}$ & $\begin{array}{l}\text { Cobalt } \\
\text { (mg/kg) }\end{array}$ & $\begin{array}{l}\text { Copper } \\
\text { (mg/kg) }\end{array}$ & $\begin{array}{c}\text { Iron } \\
\text { (mg/kg) }\end{array}$ & $\begin{array}{c}\text { Lead } \\
(\mathrm{mg} / \mathrm{kg})\end{array}$ & $\begin{array}{l}\text { Lithium } \\
\text { (mg/kg) }\end{array}$ & $\begin{array}{l}\text { Magnesium } \\
\text { (mg/kg) }\end{array}$ \\
\hline \multicolumn{17}{|c|}{ Replicate soil sample pairs } \\
\hline 435234103274500 & S-1 & $06 / 20 / 2012$ & 13,000 & $<0.38$ & 24 & 160 & 0.85 & E0.230 & 3,100 & 24 & 6.3 & 15 & 19,000 & 9.6 & 42 & 4,800 \\
\hline 435234103274500 & S-1 & $06 / 20 / 2012$ & 13,000 & $<0.38$ & 24 & 160 & 0.84 & 0.22 & 3,000 & 23 & 6.2 & 14 & 18,000 & 10 & 40 & 4,700 \\
\hline 435327103290600 & $\mathrm{P}-2$ & 06/06/2013 & 2,200 & $<0.36$ & 19 & 35 & E0.24 & E0.130 & 1,200 & 3 & 1.8 & 7.3 & 4,100 & 4.2 & 9.1 & 620 \\
\hline 435327103290600 & $\mathrm{P}-2$ & $06 / 06 / 2013$ & 2,000 & $<0.36$ & 16 & 37 & 0.21 & 0.12 & 1,000 & 2.7 & 2.6 & 6.6 & 3,700 & 3.8 & 8.2 & 560 \\
\hline \multicolumn{17}{|c|}{ Relative percent differences } \\
\hline 435234103274500 & S-1 & $06 / 20 / 2012$ & 0.0 & 0.0 & 0.0 & 0.0 & 1.2 & 4.4 & 3.3 & 4.3 & 1.6 & 6.9 & 5.4 & 0.0 & 4.9 & 2.1 \\
\hline 435327103290600 & $\mathrm{P}-2$ & $06 / 06 / 2013$ & 9.5 & 0.0 & 17.1 & 5.6 & 13.3 & 8.0 & 18.2 & 10.5 & 36.4 & 10.1 & 10.3 & 10.0 & 10.4 & 10.2 \\
\hline
\end{tabular}

\begin{tabular}{|c|c|c|c|c|c|c|c|c|c|c|c|c|c|c|}
\hline $\begin{array}{l}\text { USGS station } \\
\text { number }\end{array}$ & $\begin{array}{c}\text { Map } \\
\text { number } \\
\text { (fig. 1) }\end{array}$ & Date & $\begin{array}{c}\text { Manganese } \\
\text { (mg/kg) }\end{array}$ & $\begin{array}{l}\text { Molybdenum } \\
(\mathrm{mg} / \mathrm{kg})\end{array}$ & $\begin{array}{l}\text { Nickel } \\
\text { (mg/kg) }\end{array}$ & $\begin{array}{l}\text { Potassium } \\
\text { (mg/kg) }\end{array}$ & $\begin{array}{l}\text { Selenium } \\
(\mathrm{mg} / \mathrm{kg})\end{array}$ & $\begin{array}{l}\text { Sodium } \\
\text { (mg/kg) }\end{array}$ & $\begin{array}{l}\text { Strontium } \\
(\mathrm{mg} / \mathrm{kg})\end{array}$ & $\begin{array}{l}\text { Thallium } \\
\text { (mg/kg) }\end{array}$ & $\begin{array}{l}\text { Titanium } \\
\text { (mg/kg) }\end{array}$ & $\begin{array}{c}\text { Vanadium } \\
\text { (mg/kg) }\end{array}$ & $\begin{array}{c}\text { Zinc } \\
(\mathrm{mg} / \mathrm{kg})\end{array}$ & $\begin{array}{c}\text { Perchlorate } \\
(\mu \mathrm{g} / \mathrm{kg})\end{array}$ \\
\hline \multicolumn{15}{|c|}{ Replicate soil sample pairs } \\
\hline 435234103274500 & S-1 & $06 / 20 / 2012$ & 450 & $<0.26$ & 17 & 6,100 & $<0.87$ & $<60$ & 18 & $<0.66$ & 970 & 26 & 75 & 0.78 \\
\hline 435234103274500 & S-1 & $06 / 20 / 2012$ & 450 & $<0.26$ & 16 & 5,700 & $<0.87$ & $<60$ & 19 & $<0.66$ & 920 & 25 & 74 & 0.74 \\
\hline 435327103290600 & $\mathrm{P}-2$ & $06 / 06 / 2013$ & 240 & $<0.25$ & 6 & 780 & $<0.81$ & $<56$ & 5.1 & $<0.62$ & 100 & 4.6 & 16 & E0.29 \\
\hline 435327103290600 & $\mathrm{P}-2$ & $06 / 06 / 2013$ & 310 & $<0.25$ & 6.2 & 690 & $<0.81$ & $<56$ & 4.9 & $<0.62$ & 87 & 4.3 & 14 & 0.19 \\
\hline \multicolumn{15}{|c|}{ Relative percent differences } \\
\hline 435234103274500 & S-1 & $06 / 20 / 2012$ & 0.0 & 0.0 & 6.1 & 6.8 & 0.0 & 0.0 & 5.4 & 0.0 & 5.3 & 3.9 & 1.3 & 5.3 \\
\hline 435327103290600 & $\mathrm{P}-2$ & $06 / 06 / 2013$ & 25.5 & 0.0 & 3.3 & 12.2 & 0.0 & 0.0 & 4.0 & 0.0 & 13.9 & 6.7 & 13.3 & 42 \\
\hline
\end{tabular}

${ }^{1}$ Soil concentrations reported with an "E" preceding the value are either (1) below the minimum reporting level but greater than the established method detection limit, or (2) exceed the upper calibration range of the instrument. 
Table 5. Statistical summary of water-quality information for groundwater and surface-water sampling sites within and adjacent to Mount Rushmore National Memorial, 2011-15.

[USGS, U.S. Geological Survey; mg/L, milligrams per liter; $\mu \mathrm{S} / \mathrm{cm}$, microsiemens per centimeter at 25 degrees Celsius; $\mu \mathrm{g} / \mathrm{L}$, micrograms per liter; <, less than; SW, surface water; GW, groundwater; --, not available]

\begin{tabular}{|c|c|c|c|c|c|c|c|c|c|c|c|c|c|c|c|c|}
\hline $\begin{array}{c}\text { Map number } \\
\text { (site type) } \\
\text { (USGS station } \\
\text { number) }\end{array}$ & Statistic & $\begin{array}{c}\text { Dissolved } \\
\text { oxygen } \\
\text { (mg/L) }\end{array}$ & $\begin{array}{c}\text { pH } \\
\text { (standard } \\
\text { units) }\end{array}$ & $\begin{array}{c}\text { Specific } \\
\text { conductance } \\
(\mu \mathrm{S} / \mathrm{cm})\end{array}$ & $\begin{array}{c}\text { Water } \\
\text { temperature } \\
\text { (degrees } \\
\text { Celsius) } \\
\end{array}$ & $\begin{array}{c}\text { Calcium } \\
\text { (mg/L) }\end{array}$ & $\begin{array}{l}\text { Magnesium } \\
\quad(\mathrm{mg} / \mathrm{L})\end{array}$ & $\begin{array}{l}\text { Aluminum } \\
\text { (mg/L) }\end{array}$ & $\begin{array}{c}\text { Barium } \\
(\mu \mathrm{g} / \mathrm{L})\end{array}$ & $\begin{array}{l}\text { Copper } \\
(\mu \mathrm{g} / \mathrm{L})\end{array}$ & $\begin{array}{l}\text { Lithium } \\
\text { ( } \mu \mathrm{g} / \mathrm{L})\end{array}$ & $\begin{array}{l}\text { Strontium } \\
(\mu \mathrm{g} / \mathrm{L})\end{array}$ & $\begin{array}{c}\text { Zinc } \\
(\mu \mathrm{g} / \mathrm{L})\end{array}$ & $\begin{array}{c}\text { Antimony } \\
(\mu \mathrm{g} / \mathrm{L})\end{array}$ & $\begin{array}{c}\text { Arsenic } \\
(\mu \mathrm{g} / \mathrm{L})\end{array}$ & $\begin{array}{c}\text { Perchlorate } \\
\text { ( } \mu \mathrm{g} / \mathrm{L})\end{array}$ \\
\hline L-1 & Minimum & 7.0 & 7.2 & 546 & 12.4 & 14.0 & 2.90 & 14.4 & 5.0 & 2.7 & 23.2 & 49.1 & 22.0 & $<0.18$ & 9.7 & 2.2 \\
\hline (stream [SW]) & Median & 8.0 & 7.5 & 612 & 16.4 & 15.6 & 3.38 & 51.6 & 7.6 & 5.5 & 29.1 & 63.0 & 29.3 & $<0.18$ & 10.9 & 15 \\
\hline \multirow[t]{3}{*}{$(435250103270400)$} & Mean & 8.1 & 7.5 & 614 & 16.5 & 15.8 & 3.48 & 56.2 & 8.3 & 10.7 & 28.2 & 64.9 & 31.5 & $<0.18$ & 11.9 & 14 \\
\hline & Maximum & 9.7 & 8.1 & 695 & 19.9 & 18.1 & 4.44 & 134 & 13.1 & 26.8 & 30.6 & 87.9 & 41.3 & 0.24 & 15.0 & 24 \\
\hline & Count & 6 & 6 & 6 & 6 & 6 & 6 & 6 & 6 & 6 & 6 & 6 & 6 & 6 & 6 & 6 \\
\hline $\mathrm{L}-2$ & Minimum & 7.3 & 5.7 & 79 & 8.9 & 6.4 & 1.78 & 88.4 & 12.6 & $<0.70$ & 14.6 & 32.9 & $<2.0$ & $<0.18$ & 14.1 & 21 \\
\hline (spring [SW]) & Median & 8.2 & 6.6 & 95 & 10.2 & 7.0 & 1.88 & 195 & 14.0 & 0.6 & 20.9 & 35.6 & $<3.0$ & $<0.18$ & 15.3 & 47 \\
\hline \multirow[t]{3}{*}{ (435300103270800) } & Mean & 8.7 & 6.5 & 119 & 10.5 & 7.0 & 1.92 & 301 & 15.3 & 0.7 & 20.5 & 35.1 & 1.58 & $<0.18$ & 15.5 & 43 \\
\hline & Maximum & 11.4 & 6.9 & 265 & 13.8 & 7.4 & 2.15 & 986 & 21.5 & 1.8 & 22.7 & 36.4 & 4.40 & $<0.18$ & 17.3 & 54 \\
\hline & Count & 14 & 14 & 14 & 14 & 12 & 12 & 12 & 12 & 12 & 12 & 12 & 12 & 12 & 12 & 14 \\
\hline L-3 & Minimum & 3.0 & 5.6 & 115 & 9.0 & 10.1 & 2.54 & 81.1 & 16.6 & $\left({ }^{1}\right)$ & 25.4 & 50.0 & $\left({ }^{1}\right)$ & $<0.18$ & 13.8 & 17 \\
\hline (well [GW]) & Median & 3.6 & 6.2 & 123 & 10.4 & 10.8 & 2.73 & 124 & 17.5 & $\left({ }^{1}\right)$ & 27.1 & 53.1 & $\left({ }^{1}\right)$ & $<0.18$ & 14.7 & 23 \\
\hline \multirow[t]{3}{*}{ (435300103265001) } & Mean & 3.9 & 6.1 & 123 & 10.2 & 10.8 & 2.71 & 140 & 17.7 & $\left({ }^{1}\right)$ & 27.2 & 53.1 & $\left({ }^{1}\right)$ & $<0.18$ & 14.8 & 25 \\
\hline & Maximum & 6.4 & 6.7 & 135 & 11.8 & 11.6 & 2.85 & 260 & 20.0 & $\left({ }^{1}\right)$ & 30.6 & 56.5 & $\left({ }^{1}\right)$ & $<0.18$ & 18.1 & 38 \\
\hline & Count & 13 & 17 & 17 & 17 & 14 & 14 & 14 & 14 & $\left({ }^{1}\right)$ & 14 & 14 & $\left({ }^{1}\right)$ & 14 & 14 & 17 \\
\hline L-4 & Minimum & 2.0 & 6.2 & 101 & 10.3 & 8.8 & 2.30 & 31.1 & 8.0 & $\left({ }^{1}\right)$ & 28.7 & 43.7 & $\left({ }^{1}\right)$ & $<0.18$ & 22.7 & 2.1 \\
\hline (well [GW]) & Median & 2.8 & 6.4 & 108 & 11.2 & 9.2 & 2.44 & 109 & 10.3 & $\left({ }^{1}\right)$ & 31.0 & 46.1 & $\left({ }^{1}\right)$ & $<0.18$ & 26.6 & 6.1 \\
\hline \multirow[t]{3}{*}{ (435302103270501) } & Mean & 3.2 & 6.4 & 109 & 11.1 & 9.3 & 2.50 & 113 & 10.4 & $\left({ }^{1}\right)$ & 31.3 & 46.6 & $\left({ }^{1}\right)$ & $<0.18$ & 26.5 & 7.6 \\
\hline & Maximum & 5.5 & 6.7 & 127 & 12.1 & 10.1 & 2.97 & 268 & 12.4 & $\left({ }^{1}\right)$ & 33.6 & 50.4 & $\left({ }^{1}\right)$ & $<0.18$ & 29.2 & 17 \\
\hline & Count & 13 & 14 & 14 & 14 & 14 & 14 & 14 & 14 & $\left({ }^{1}\right)$ & 14 & 14 & $\left({ }^{1}\right)$ & 14 & 14 & 14 \\
\hline L-5 & Minimum & 8.5 & 6.8 & 224 & 8.5 & 21.0 & 4.99 & 59.6 & 46.7 & $<0.70$ & 33.8 & 100 & $<2.0$ & $<0.18$ & 20.0 & 6.2 \\
\hline (stream [SW]) & Median & 9.2 & 7.9 & 412 & 12.6 & 24.9 & 6.48 & 97.6 & 63.7 & 1.9 & 36.7 & 114 & 4.60 & $<0.18$ & 25.5 & 14 \\
\hline \multirow[t]{3}{*}{ (435302103265300) } & Mean & 9.5 & 7.8 & 401 & 12.5 & 25.9 & 6.48 & 119 & 65.3 & 1.9 & 36.9 & 120 & 4.14 & $<0.18$ & 25.0 & 14 \\
\hline & Maximum & 12.1 & 8.2 & 600 & 15.5 & 32.5 & 8.59 & 221 & 87.7 & 2.8 & 40.1 & 152 & 8.30 & $<0.18$ & 30.6 & 18 \\
\hline & Count & 11 & 11 & 11 & 11 & 11 & 11 & 11 & 11 & 11 & 11 & 11 & 11 & 11 & 11 & 11 \\
\hline L-6 & Minimum & -- & 6.7 & 170 & 7.0 & 16.5 & 4.85 & 171 & 30.2 & $\left({ }^{1}\right)$ & 68.6 & 81.3 & $\left({ }^{1}\right)$ & $<0.18$ & 69.7 & $<0.20$ \\
\hline (well [GW]) & Median & -- & 6.7 & 170 & 7.0 & 16.5 & 4.85 & 171 & 30.2 & $\left({ }^{1}\right)$ & 68.6 & 81.3 & $\left({ }^{1}\right)$ & $<0.18$ & 69.7 & $<0.20$ \\
\hline \multirow[t]{3}{*}{ (435312103264801) } & Mean & -- & 6.7 & 170 & 7.0 & 16.5 & 4.85 & 171 & 30.2 & $\left({ }^{1}\right)$ & 68.6 & 81.3 & $\left({ }^{1}\right)$ & $<0.18$ & 69.7 & $<0.20$ \\
\hline & Maximum & -- & 6.7 & 170 & 7.0 & 16.5 & 4.85 & 171 & 30.2 & $\left({ }^{1}\right)$ & 68.6 & 81.3 & $\left({ }^{1}\right)$ & $<0.18$ & 69.7 & $<0.20$ \\
\hline & Count & 0 & 1 & 1 & 1 & 1 & 1 & 1 & 1 & $\left({ }^{1}\right)$ & 1 & 1 & $\left({ }^{1}\right)$ & 1 & 1 & 1 \\
\hline
\end{tabular}


Table 5. Statistical summary of water-quality information for groundwater and surface-water sampling sites within and adjacent to Mount Rushmore National Memorial, 2011-15.-Continued

[USGS, U.S. Geological Survey; mg/L, milligrams per liter; $\mu \mathrm{S} / \mathrm{cm}$, microsiemens per centimeter at 25 degrees Celsius; $\mu \mathrm{g} / \mathrm{L}$, micrograms per liter; <, less than; SW, surface water; GW, groundwater; --, not available]

\begin{tabular}{|c|c|c|c|c|c|c|c|c|c|c|c|c|c|c|c|c|}
\hline $\begin{array}{c}\text { Map number } \\
\text { (site type) } \\
\text { (USGS station } \\
\text { number) }\end{array}$ & Statistic & $\begin{array}{c}\text { Dissolved } \\
\text { oxygen } \\
\text { (mg/L) }\end{array}$ & $\begin{array}{c}\text { pH } \\
\text { (standard } \\
\text { units) }\end{array}$ & $\begin{array}{c}\text { Specific } \\
\text { conductance } \\
(\mu \mathrm{S} / \mathrm{cm})\end{array}$ & $\begin{array}{c}\text { Water } \\
\text { temperature } \\
\text { (degrees } \\
\text { Celsius) }\end{array}$ & $\begin{array}{l}\text { Calcium } \\
\text { (mg/L) }\end{array}$ & $\begin{array}{l}\text { Magnesium } \\
\quad(\mathrm{mg} / \mathrm{L})\end{array}$ & $\begin{array}{l}\text { Aluminum } \\
\text { (mg/L) }\end{array}$ & $\begin{array}{c}\text { Barium } \\
(\mu \mathrm{g} / \mathrm{L})\end{array}$ & $\begin{array}{c}\text { Copper } \\
(\mu \mathrm{g} / \mathrm{L})\end{array}$ & $\begin{array}{l}\text { Lithium } \\
\text { ( } \mu \mathrm{g} / \mathrm{L})\end{array}$ & $\begin{array}{l}\text { Strontium } \\
(\mu \mathrm{g} / \mathrm{L})\end{array}$ & $\begin{array}{l}\text { Zinc } \\
(\mu \mathrm{g} / \mathrm{L})\end{array}$ & $\begin{array}{c}\text { Antimony } \\
(\mu \mathrm{g} / \mathrm{L})\end{array}$ & $\begin{array}{c}\text { Arsenic } \\
(\mu \mathrm{g} / \mathrm{L})\end{array}$ & $\begin{array}{c}\text { Perchlorate } \\
(\mu \mathrm{g} / \mathrm{L})\end{array}$ \\
\hline L-7 & Minimum & 8.3 & 6.8 & 160 & 6.6 & 10.4 & 2.55 & $<3.8$ & 13.3 & $(1)$ & 26.6 & 50.1 & $\left({ }^{1}\right)$ & $<0.18$ & 1.3 & 16 \\
\hline (well [GW]) & Median & 9.2 & 7.1 & 190 & 10.6 & 11.0 & 2.63 & 5.5 & 15.6 & $\left({ }^{1}\right)$ & 27.6 & 55.8 & $\left({ }^{1}\right)$ & $<0.18$ & 2.7 & 20 \\
\hline \multirow[t]{3}{*}{ (435302103270201) } & Mean & 9.1 & 7.1 & 181 & 10.5 & 11.0 & 2.64 & 5.2 & 15.4 & $\left({ }^{1}\right)$ & 28.3 & 55.2 & $\left({ }^{1}\right)$ & $<0.18$ & 2.5 & 22 \\
\hline & Maximum & 10.0 & 7.7 & 195 & 13.8 & 11.5 & 2.78 & 7.2 & 16.8 & $\left({ }^{1}\right)$ & 30.8 & 58.0 & $\left({ }^{1}\right)$ & $<0.18$ & 3.1 & 29 \\
\hline & Count & 5 & 5 & 5 & 5 & 6 & 6 & 6 & 6 & $\left({ }^{1}\right)$ & 6 & 6 & $\left({ }^{1}\right)$ & 6 & 6 & 6 \\
\hline L-8 & Minimum & 11.2 & 5.6 & 33 & 5.4 & 1.5 & 0.28 & 76.0 & 12.1 & 5.3 & 0.8 & 10.8 & 6.20 & 0.21 & 0.4 & 33 \\
\hline (stream [SW]) & Median & 11.6 & 5.8 & 39 & 7.7 & 1.5 & 0.28 & 76.0 & 12.1 & 5.3 & 0.8 & 10.8 & 6.20 & 0.21 & 0.4 & 34 \\
\hline \multirow[t]{3}{*}{ (435245103273000) } & Mean & 11.6 & 5.8 & 39 & 7.7 & 1.5 & 0.28 & 76.0 & 12.1 & 5.3 & 0.8 & 10.8 & 6.20 & 0.21 & 0.4 & 34 \\
\hline & Maximum & 12.0 & 6.0 & 45 & 10.0 & 1.5 & 0.28 & 76.0 & 12.1 & 5.3 & 0.8 & 10.8 & 6.20 & 0.21 & 0.4 & 35 \\
\hline & Count & 2 & 2 & 2 & 2 & 1 & 1 & 1 & 1 & 1 & 1 & 1 & 1 & 1 & 1 & 2 \\
\hline G-1 & Minimum & 10.2 & 6.3 & 399 & 9.3 & -- & -- & -- & -- & -- & -- & -- & -- & -- & -- & $<0.280$ \\
\hline (spring $[\mathrm{SW}]$ ) & Median & 10.2 & 6.3 & 399 & 9.3 & -- & -- & -- & -- & -- & -- & -- & -- & -- & -- & $<0.280$ \\
\hline \multirow[t]{3}{*}{ (435231103265101) } & Mean & 10.2 & 6.3 & 399 & 9.3 & -- & -- & -- & -- & -- & -- & -- & -- & -- & -- & $<0.280$ \\
\hline & Maximum & 10.2 & 6.3 & 399 & 9.3 & -- & -- & -- & -- & -- & -- & -- & -- & -- & -- & $<0.280$ \\
\hline & Count & 1 & 1 & 1 & 1 & 0 & 0 & 0 & 0 & 0 & 0 & 0 & 0 & 0 & 0 & 1 \\
\hline G-2 & Minimum & 7.6 & 6.3 & 352 & 5.3 & 31.7 & 7.30 & 10.4 & 68.2 & 0.4 & 25.2 & 138 & 1.00 & $<0.18$ & 1.4 & 0.06 \\
\hline (stream $[\mathrm{SW}]$ ) & Median & 9.2 & 6.6 & 433 & 13.8 & 44.0 & 10.0 & 28.9 & 86.6 & 0.4 & 31.6 & 174 & 1.25 & $<0.18$ & 2.2 & 0.10 \\
\hline \multirow[t]{3}{*}{ (435234103262600) } & Mean & 9.2 & 6.8 & 429 & 11.9 & 43.1 & 9.57 & 69.1 & 84.9 & 0.8 & 31.7 & 174 & 1.25 & $<0.18$ & 2.2 & 0.11 \\
\hline & Maximum & 11.2 & 7.7 & 501 & 15.9 & 50.8 & 11.5 & 222 & 101.0 & 2.2 & 40.2 & 200 & 1.50 & $<0.18$ & 3.1 & 0.14 \\
\hline & Count & 8 & 10 & 10 & 10 & 8 & 8 & 8 & 8 & 8 & 8 & 8 & 8 & 8 & 8 & 10 \\
\hline G-3 & Minimum & 0.5 & 6.3 & 430 & 8.2 & 49.2 & 16.2 & 5.5 & 62.1 & $\left({ }^{1}\right)$ & 60.5 & 244 & $\left({ }^{1}\right)$ & $<0.18$ & 1.4 & $<0.0088$ \\
\hline (well [GW]) & Median & 6.4 & 6.9 & 433 & 8.6 & 51.6 & 16.4 & 6.5 & 69.1 & $\left({ }^{1}\right)$ & 62.6 & 254 & $\left({ }^{1}\right)$ & $<0.18$ & 6.5 & 0.06 \\
\hline \multirow[t]{3}{*}{ (435242103261801) } & Mean & 4.9 & 6.7 & 433 & 10.5 & 51.2 & 16.4 & 6.5 & 66.9 & $\left({ }^{1}\right)$ & 62.6 & 255 & $\left({ }^{1}\right)$ & $<0.18$ & 5.4 & 0.06 \\
\hline & Maximum & 7.8 & 6.9 & 435 & 14.8 & 52.9 & 16.6 & 7.5 & 69.4 & $\left({ }^{1}\right)$ & 64.8 & 268 & $\left({ }^{1}\right)$ & $<0.18$ & 8.3 & $<0.20$ \\
\hline & Count & 3 & 3 & 3 & 3 & 3 & 3 & 3 & 3 & $\left({ }^{1}\right)$ & 3 & 3 & $\left({ }^{1}\right)$ & 3 & 3 & 3 \\
\hline S-1 & Minimum & 3.3 & 5.8 & 24 & 10.6 & 16.7 & 3.45 & 17.2 & 54.4 & $<0.80$ & 6.2 & 77.0 & 1.00 & $<0.18$ & 5.8 & 2.5 \\
\hline (stream [SW]) & Median & 6.3 & 6.1 & 277 & 11.6 & 22.7 & 4.74 & 43.0 & 73.9 & 0.9 & 7.4 & 105 & 1.00 & $<0.18$ & 6.5 & 3.4 \\
\hline \multirow[t]{3}{*}{ (435234103274500) } & Mean & 6.9 & 6.3 & 216 & 11.9 & 22.7 & 4.74 & 43.0 & 73.9 & 0.9 & 7.4 & 105 & 1.00 & $<0.18$ & 6.5 & 6.7 \\
\hline & Maximum & 9.9 & 6.8 & 314 & 13.9 & 28.7 & 6.03 & 68.8 & 93.4 & 1.3 & 8.6 & 132 & 1.00 & $<0.18$ & 7.2 & 19 \\
\hline & Count & 5 & 5 & 5 & 5 & 2 & 2 & 2 & 2 & 2 & 2 & 2 & 2 & 2 & 2 & 5 \\
\hline
\end{tabular}


Table 5. Statistical summary of water-quality information for groundwater and surface-water sampling sites within and adjacent to Mount Rushmore National Memorial,

2011-15.-Continued

[USGS, U.S. Geological Survey; mg/L, milligrams per liter; $\mu \mathrm{S} / \mathrm{cm}$, microsiemens per centimeter at 25 degrees Celsius; $\mu \mathrm{g} / \mathrm{L}$, micrograms per liter; <, less than; SW, surface water; GW, groundwater; --, not available

\begin{tabular}{|c|c|c|c|c|c|c|c|c|c|c|c|c|c|c|c|c|}
\hline $\begin{array}{c}\text { Map number } \\
\text { (site type) } \\
\text { (USGS station } \\
\text { number) }\end{array}$ & Statistic & $\begin{array}{c}\text { Dissolved } \\
\text { oxygen } \\
\text { (mg/L) }\end{array}$ & $\begin{array}{c}\text { pH } \\
\text { (standard } \\
\text { units) }\end{array}$ & $\begin{array}{c}\text { Specific } \\
\text { conductance } \\
(\mu \mathrm{S} / \mathrm{cm})\end{array}$ & $\begin{array}{c}\text { Water } \\
\text { temperature } \\
\text { (degrees } \\
\text { Celsius) }\end{array}$ & $\begin{array}{c}\text { Calcium } \\
\text { (mg/L) }\end{array}$ & $\begin{array}{l}\text { Magnesium } \\
\quad(\mathrm{mg} / \mathrm{L})\end{array}$ & $\begin{array}{l}\text { Aluminum } \\
(\mathrm{mg} / \mathrm{L})\end{array}$ & $\begin{array}{c}\text { Barium } \\
(\mu \mathrm{g} / \mathrm{L})\end{array}$ & $\begin{array}{c}\text { Copper } \\
\text { ( } \mu \mathrm{g} / \mathrm{L})\end{array}$ & $\begin{array}{l}\text { Lithium } \\
(\mu \mathrm{g} / \mathrm{L})\end{array}$ & $\begin{array}{c}\text { Strontium } \\
(\mu \mathrm{g} / \mathrm{L})\end{array}$ & $\begin{array}{c}\text { Zinc } \\
(\mu \mathrm{g} / \mathrm{L})\end{array}$ & $\begin{array}{c}\text { Antimony } \\
(\mu \mathrm{g} / \mathrm{L})\end{array}$ & $\begin{array}{c}\text { Arsenic } \\
(\mu \mathrm{g} / \mathrm{L})\end{array}$ & $\begin{array}{c}\text { Perchlorate } \\
(\mu \mathrm{g} / \mathrm{L})\end{array}$ \\
\hline $\mathrm{S}-2$ & Minimum & 6.5 & 5.9 & 309 & 3.6 & 20.7 & 6.42 & 10.6 & 46.8 & $<0.70$ & 13.9 & 94.3 & 1.00 & $<0.18$ & 2.3 & 0.61 \\
\hline (stream $[\mathrm{SW}]$ ) & Median & 8.3 & 6.3 & 400 & 11.8 & 28.5 & 8.18 & 36.9 & 70.3 & $<0.80$ & 18.5 & 136 & 1.00 & $<0.18$ & 4.0 & 1.8 \\
\hline \multirow[t]{3}{*}{$(435214103273500)$} & Mean & 9.1 & 6.4 & 394 & 9.3 & 27.7 & 7.98 & 109 & 68.2 & 0.9 & 18.2 & 131 & 1.51 & $<0.18$ & 3.9 & 1.7 \\
\hline & Maximum & 11.5 & 7.1 & 455 & 14.3 & 31.8 & 9.49 & 426 & 82.8 & 2.8 & 22.1 & 151 & 3.60 & $<0.18$ & 5.4 & 2.8 \\
\hline & Count & 5 & 7 & 7 & 7 & 7 & 7 & 7 & 7 & 7 & 7 & 7 & 7 & 7 & 7 & 7 \\
\hline $\mathrm{P}-1$ & Minimum & 0.5 & 5.4 & 208 & 9.8 & 19.7 & 5.08 & 12.0 & 36.8 & $\left({ }^{1}\right)$ & 85.8 & 94.5 & $\left({ }^{1}\right)$ & $<0.18$ & 61.5 & $<0.0088$ \\
\hline (well [GW]) & Median & 4.9 & 6.1 & 209 & 9.9 & 19.8 & 5.20 & 89.6 & 38.1 & $\left({ }^{1}\right)$ & 93.6 & 96.8 & $\left({ }^{1}\right)$ & $<0.18$ & 83.8 & 0.06 \\
\hline \multirow[t]{3}{*}{$(435342103285801)$} & Mean & 4.0 & 5.9 & 212 & 9.9 & 19.9 & 5.20 & 182 & 38.6 & $\left({ }^{1}\right)$ & 92.0 & 96.6 & $\left({ }^{1}\right)$ & $<0.18$ & 108 & 0.05 \\
\hline & Maximum & 6.5 & 6.1 & 218 & 10.0 & 20.2 & 5.31 & 444 & 41.0 & $\left({ }^{1}\right)$ & 96.6 & 98.6 & $\left(\begin{array}{l}1 \\
)\end{array}\right.$ & $<0.18$ & 178 & $<0.20$ \\
\hline & Count & 3 & 3 & 3 & 3 & 3 & 3 & 3 & 3 & $\left({ }^{1}\right)$ & 3 & 3 & $\left({ }^{1}\right)$ & 3 & 3 & 3 \\
\hline $\mathrm{P}-2$ & Minimum & 8.6 & 6.0 & 55 & 10.3 & 4.0 & 1.43 & 69.4 & 14.1 & $<0.70$ & 7.4 & 22.9 & $<2.0$ & $<0.18$ & 3.1 & 0.05 \\
\hline (stream [SW]) & Median & 9.0 & 6.1 & 56 & 10.8 & 4.4 & 1.45 & 298 & 16.7 & 1.1 & 10.8 & 24.0 & 1.50 & $<0.18$ & 5.6 & 0.12 \\
\hline \multirow[t]{3}{*}{$(435327103290600)$} & Mean & 9.1 & 6.4 & 56 & 11.5 & 4.3 & 1.44 & 569 & 18.7 & 1.2 & 10.4 & 23.8 & 2.10 & $<0.18$ & 5.5 & 0.10 \\
\hline & Maximum & 9.6 & 7.0 & 58 & 13.5 & 4.5 & 1.45 & 1340 & 25.2 & 2.1 & 13.1 & 24.4 & 3.80 & $<0.18$ & 7.8 & 0.13 \\
\hline & Count & 3 & 3 & 3 & 3 & 3 & 3 & 3 & 3 & 3 & 3 & 3 & 3 & 3 & 3 & 3 \\
\hline $\mathrm{I}-1$ & Minimum & 8.3 & 6.5 & 68 & 12.4 & 7.5 & 2.04 & 56.1 & 25.6 & 1.0 & 7.9 & 30.8 & 1.50 & $<0.18$ & 2.1 & 0.11 \\
\hline (stream [SW]) & Median & 9.0 & 6.8 & 79 & 12.6 & 11.5 & 2.07 & 748 & 28.2 & 1.9 & 8.6 & 30.9 & 4.90 & $<0.18$ & 3.1 & 0.12 \\
\hline \multirow[t]{3}{*}{$(435044103241000)$} & Mean & 9.1 & 7.0 & 86 & 13.5 & 16.1 & 2.37 & 524 & 28.7 & 1.7 & 9.4 & 36.4 & 4.10 & $<0.18$ & 2.8 & 0.13 \\
\hline & Maximum & 10.1 & 7.6 & 110 & 15.5 & 29.4 & 3.00 & 769 & 32.4 & 2.1 & 11.7 & 47.5 & 5.90 & $<0.18$ & 3.1 & 0.16 \\
\hline & Count & 3 & 3 & 3 & 3 & 3 & 3 & 3 & 3 & 3 & 3 & 3 & 3 & 3 & 3 & 3 \\
\hline
\end{tabular}

${ }^{1}$ Concentrations of zinc and copper for groundwater well sites were censored due to poor performance of quality-assurance and quality-control measures (field blanks and replicates). 


\section{Perchlorate in Groundwater and Surface Water}

Perchlorate concentrations were greatest within the Lafferty Gulch drainage basin, ranging from $<0.20$ to $38 \mu \mathrm{g} / \mathrm{L}$ in groundwater samples and $2.2-54 \mu \mathrm{g} / \mathrm{L}$ in surface-water samples (table 5). The statistical distribution of perchlorate concentrations at all sites is shown using boxplots in figure 3 . Sites within the Starling Gulch drainage basin (sites S-1 and S-2) also had some evidence of perchlorate contamination, with concentrations ranging from 0.61 to $19 \mu \mathrm{g} / \mathrm{L}$. All groundwater and surface-water samples within the drainage basin for the unnamed tributary to Grizzly Bear Creek (sites G-1, G-2, and G-3) and reference sites outside the park boundary (sites $\mathrm{P}-1, \mathrm{P}-2$, and I-1) had concentrations that were $<0.20 \mu \mathrm{g} / \mathrm{L}$. The groundwater site within Lafferty Gulch drainage basin but downstream from the park boundary (site L-6) also had a perchlorate concentration $<0.20 \mu \mathrm{g} / \mathrm{L}$ in the one sample collected from the site. Perchlorate concentrations in samples collected from the 200-ft production well (site L-3) located in the Lafferty Gulch drainage basin ranged from 17 to $38 \mu \mathrm{g} / \mathrm{L}$ with a median of $23 \mu \mathrm{g} / \mathrm{L}$, whereas samples from the 200 -ft production well (site L-4) had perchlorate concentrations that ranged from 2.1 to $17 \mu \mathrm{g} / \mathrm{L}$ with a median of $6.1 \mu \mathrm{g} / \mathrm{L}$. Perchlorate concentrations in samples from site L-7 (treated groundwater) were similar to the concentrations in samples from site L-3, which was the predominant source of water during the study period (2011-15). The slightly lower perchlorate concentrations at site L-7 compared to site L-3 are likely caused by the blending of groundwater from site L-4 (Well 2), which has lower perchlorate concentrations than site L-3, with groundwater from site L-3 (Well 1). Perchlorate concentrations in samples from site L-1 were highly variable because the flow was predominantly treated wastewater. Samples from site L-2 (springflow upstream from the production wells in the West Fork Lafferty Gulch drainage) had the greatest perchlorate concentrations among all sites, ranging from 21 to $54 \mu \mathrm{g} / \mathrm{L}$.

A time-series analyses of perchlorate concentrations at sampling sites shows little change during 2011-15 (fig. 4). At site L-3 (Well 1), perchlorate concentrations were about $20 \mu \mathrm{g} / \mathrm{L}$ during June-August 2011, and concentrations did not consistently decrease during 2012-15. Some seasonality in perchlorate concentrations is indicated at sites within the Lafferty Gulch drainage basin, because concentrations measured in May and June during 2012-14 typically were greater than concentrations measured during July and August of the same year (fig. 4). The magnitude of these differences between early and late summer was as great as $17 \mu \mathrm{g} / \mathrm{L}$ at site L-3 during 2013, whereas perchlorate concentrations at most other sites decreased by $5-10 \mu \mathrm{g} / \mathrm{L}$. The greater concentrations during the early summer months may be explained by the greater recharge preceding this period, which can cause transport of contaminants on the land surface into unconfined aquifers. Concentrations at site L-2 increased slightly from May through August 2012 from 49 to $54 \mu \mathrm{g} / \mathrm{L}$. Perchlorate concentrations in samples from sites in the Starling Gulch drainage basin (sites S-1 and S-2) generally were consistent

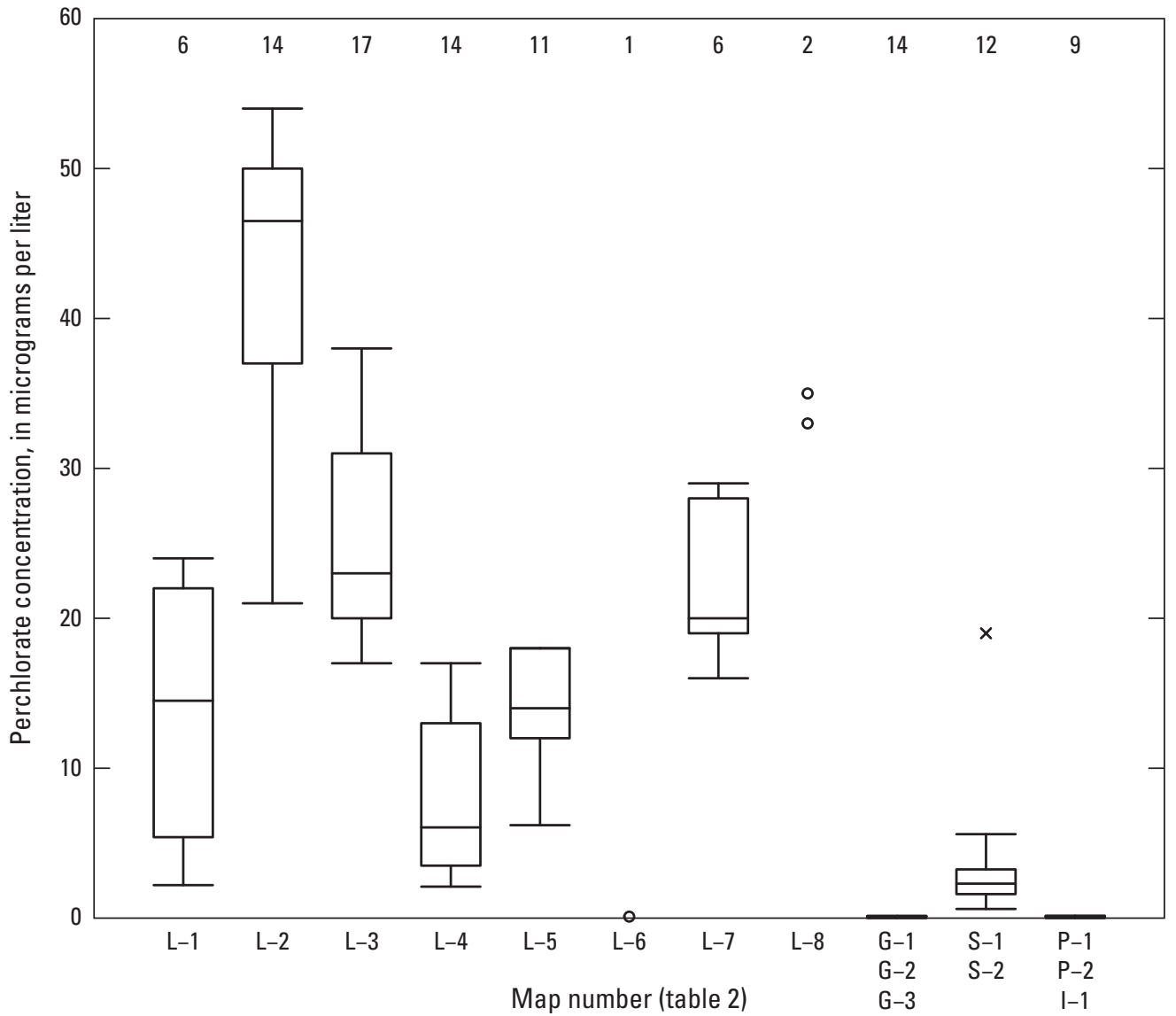

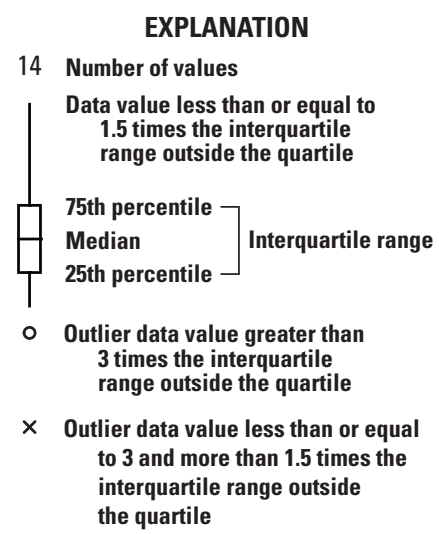

Figure 3. Perchlorate concentration in selected groundwater and surfacewater sites within and adjacent to Mount Rushmore National Memorial, 2011-15. 


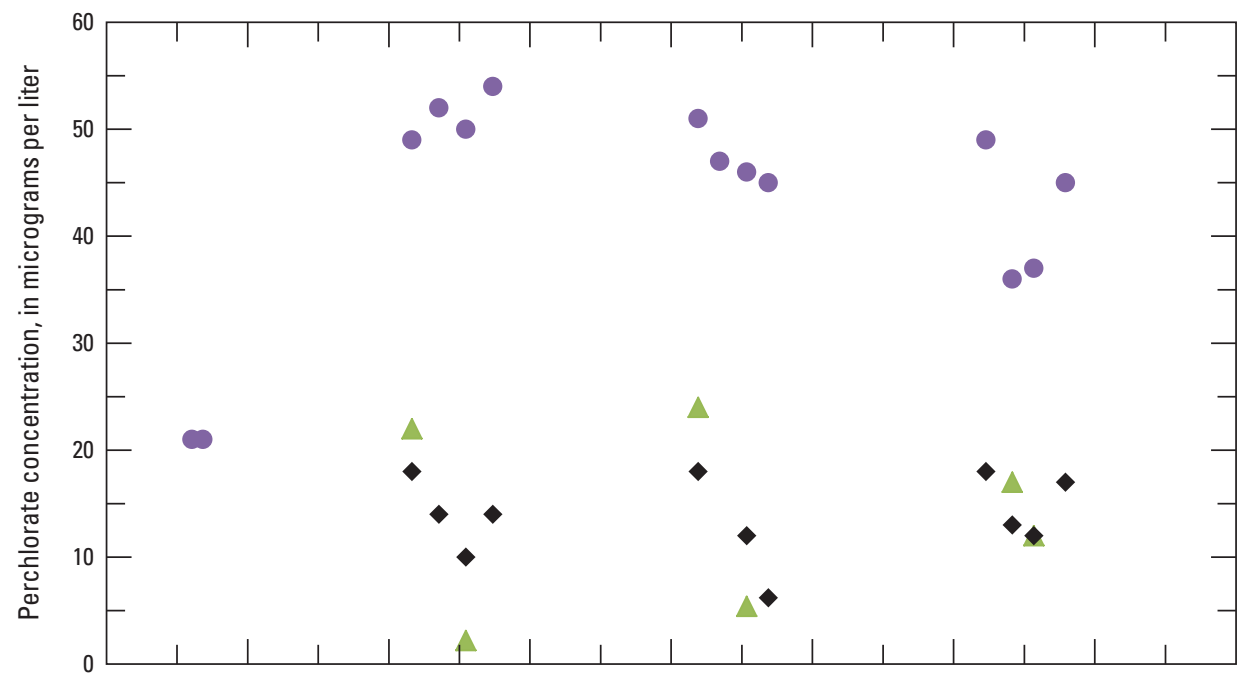

EXPLANATION

Map number (table 2)

L -1

- $L-2$

$\rightarrow \mathrm{L}-5$

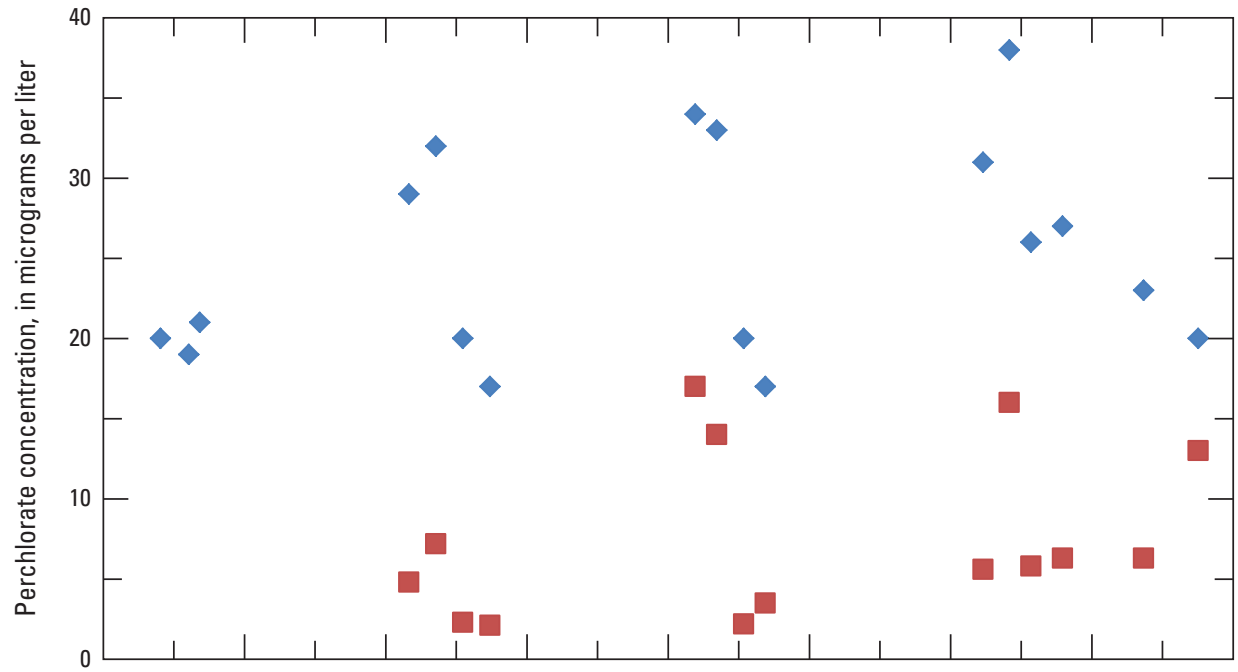

EXPLANATION

Map number (table 2)

$\mathrm{L}-3$

$\mathrm{L}-4$

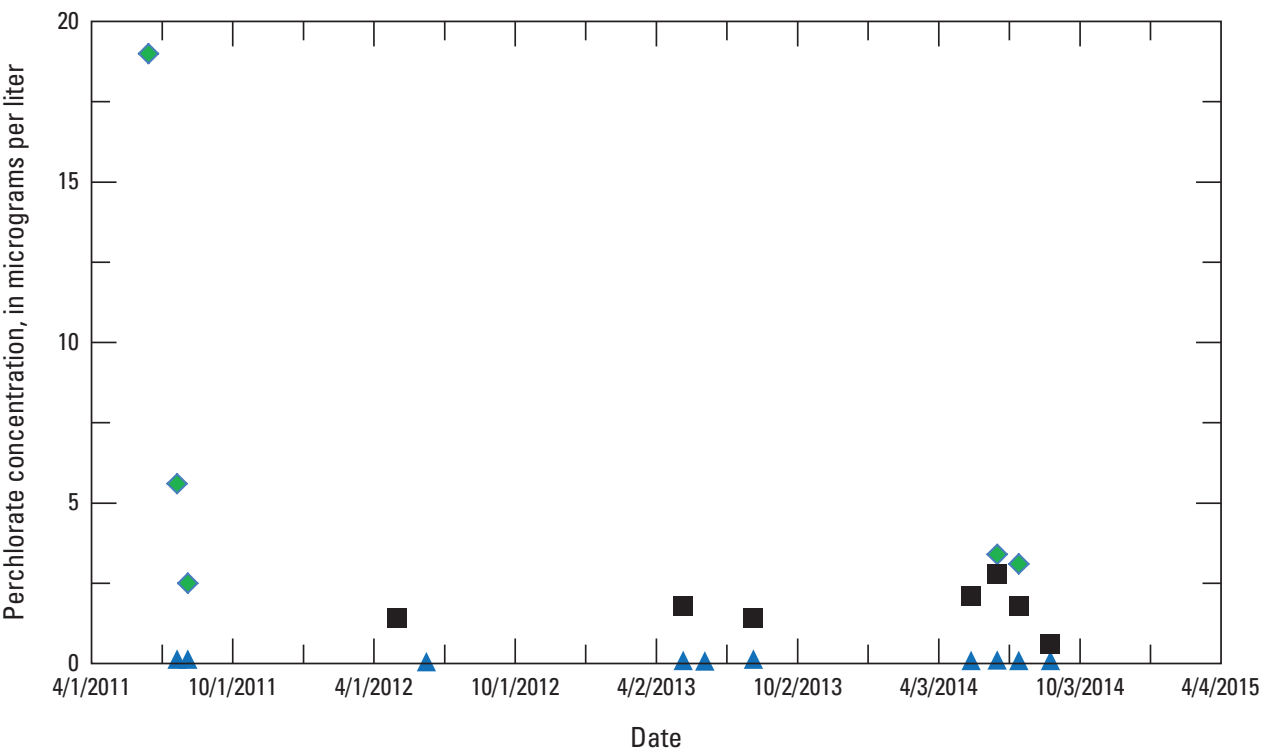

EXPLANATION

Map number (table 2)

$\checkmark \mathrm{S}-1$

- $S-2$

$\Delta \mathrm{G}-2$

Figure 4. Perchlorate concentrations at eight sampling sites within Mount Rushmore National Memorial, 2011-15. 
during 2012-14, ranging from 0.61 to $3.4 \mu \mathrm{g} / \mathrm{L}$. Perchlorate concentrations at site S-1 were greater during 2011 than during 2012-14.

\section{Perchlorate in Soil Samples}

The concentrations of perchlorate and metals in soil within different watersheds may be used to assess similarities or differences relative to point-source contamination and to natural atmospheric deposition. Perchlorate and selected metal concentrations from soil samples collected during 2012-13 are presented in table 6. Soil-sample concentrations represent conditions in the top 8 in. of soil and do not assess the geologic materials below this surficial layer. Soil samples were collected at four sites within the Hall of Records Canyon. Site L-12 is located directly behind the granite faces where fireworks were launched during 1998-2009. The other three sites (L-9, L-10, and L-11) are located in an approximate straight line course from site L-12 downgradient towards the production wells (sites L-3 and L-4; fig. 1). Soil samples were collected at an additional 7 sites previously described in the "Selection and Description of Sampling Sites" section for this study (table 2).

Perchlorate concentrations in soil samples were greatest at sites in the West Fork Lafferty Gulch drainage; these soil sites were topographically higher than the two production wells. Perchlorate in soil samples from sites L-10 and L-12 were 2.3 and $1.7 \mu \mathrm{g} / \mathrm{kg}$, respectively; concentrations at reference sites P-2 and I-1 were about an order of magnitude less ( 0.29 and $0.21 \mu \mathrm{g} / \mathrm{kg}$, respectively). Three sites in Lafferty Gulch drainage basin (sites L-1, L-5, and L-9), however, had perchlorate concentrations in soil samples less than $0.20 \mu \mathrm{g} / \mathrm{kg}$.

\section{Metal Concentrations in Groundwater and Surface Water}

Statistical summaries of concentrations for selected metals in groundwater and surface-water samples are shown in table 5 , and median concentrations for five selected metals at each site are shown in figure 5. Concentrations of antimony were all $0.21 \mu \mathrm{g} / \mathrm{L}$ or less, and most were less than the reporting level of $0.18 \mu \mathrm{g} / \mathrm{L}$, and are not shown in figure 5. Copper and zinc concentrations did not have acceptable quality-assurance and quality-control measures in groundwater well samples and are not presented for any sites in figure 5. Median concentrations of metals were similar in samples collected from sites within the Lafferty Gulch drainage basin. The greatest dissimilarity of metal concentrations among sites occurred with the greater median barium and lithium concentrations in samples from sites in the lower part of the Lafferty Gulch drainage basin (sites L-5 and L-6). Median barium and calcium concentrations were greatest in the Grizzly Bear Creek and Starling Gulch drainage basins (sites G-2, G-3, S-1, and S-2). Samples collected at reference sites (P-1, P-2, and I-1) generally had concentrations of metals within the same range as samples from sites within the park unit, presenting little evidence of metal contamination due to anthropogenic factors within the park boundary. In contrast, perchlorate concentrations in samples collected within the park Mount Rushmore National Memorial were about one magnitude higher than perchlorate concentrations in samples outside of the park unit. Sites L-8 and L-2 generally had the lowest concentrations of metals within the park unit but had the greatest concentrations of perchlorate (medians of 34 and $47 \mu \mathrm{g} / \mathrm{L}$, respectively; table 5).

Arsenic is not typically included as a metal in fireworks but was included in sample analyses to provide information on another contaminant of concern. Arsenopyrite naturally occurs in Precambrian granitic and metamorphic rocks within the Black Hills area (Betemariam and others, 2010); thus, high arsenic concentrations are common in groundwater from this area. Arsenic concentrations in untreated groundwater samples collected from production wells at Mount Rushmore National Memorial (sites L-3 and L-4) during 2011-15 frequently exceeded the EPA Maximum Contaminant Level (MCL) of $10 \mu \mathrm{g} / \mathrm{L}$ (U.S. Environmental Protection Agency, 2006), ranging from 13.8 to $29.2 \mu \mathrm{g} / \mathrm{L}$ (table 5; fig. 6; and appendix). A water treatment plant was constructed to reduce arsenic concentrations in groundwater. Treated water samples from site L-7 had a median arsenic concentration of $2.7 \mu \mathrm{g} / \mathrm{L}$ and a maximum arsenic concentration of 3.1, which are less than the MCL of $10 \mu \mathrm{g} / \mathrm{L}$. Arsenic concentrations in samples from other sites in the Lafferty Gulch drainage basin generally were in the range of 10-30 $\mu \mathrm{g} / \mathrm{L}$ (table 5). Arsenic concentrations in samples from sites in the Starling Gulch and the unnamed tributary to Grizzly Bear Creek drainage basins were lower (in the range of $1-10 \mu \mathrm{g} / \mathrm{L}$ ) than samples from sites in Lafferty Gulch drainage basin. Arsenic concentrations in surface water outside of the Mount Rushmore National Memorial park boundary (sites P-2 and I-1) ranged from 2.1 to $7.8 \mu \mathrm{g} / \mathrm{L}$. Groundwater from sites P-1 (well at Horsethief Lake) and L-6 (well in lower Lafferty Gulch drainage basin) had the highest arsenic concentrations, ranging from 61.5 to $178 \mu \mathrm{g} / \mathrm{L}$. The lowest arsenic concentration of $0.4 \mu \mathrm{g} / \mathrm{L}$ was measured at site $\mathrm{L}-8$, which is within the talus below the sculpture where water has minimal contact with schists that contain arsenopyrite.

\section{Metal Concentrations in Soil Samples}

Concentrations of the 25 metals analyzed in soils samples typically were similar among sites, and little evidence of anthropogenic contamination can be gleaned from these results; however, for 22 of the 25 metals analyzed, concentrations in soil were greater at sites within Mount Rushmore National Memorial than in samples collected at sites adjacent to the park unit (table 6). Copper and lead concentrations at site L-12 (83 and $100 \mathrm{mg} / \mathrm{kg}$, respectively) were about an order of magnitude greater than concentrations at all other sites (fig. 7). Titanium concentrations were greatest in soil samples from the Lafferty Gulch drainage basin (sites L-9 and L-10), compared to all other sites. 
Table 6. Perchlorate and selected metal concentrations in soil samples collected within and adjacent to Mount Rushmore National Memorial, $2012-13$.

[USGS, U.S. Geological Survey; mg/kg, milligrams per kilogram; $\mu \mathrm{g} / \mathrm{kg}$, micrograms per kilogram; E, estimated concentration ${ }^{1} ;<$, less than]

\begin{tabular}{|c|c|c|c|c|c|c|c|c|c|c|c|c|c|c|c|c|}
\hline $\begin{array}{c}\text { USGS station } \\
\text { number }\end{array}$ & $\begin{array}{c}\text { Map } \\
\text { number } \\
\text { (fig. 1) }\end{array}$ & Date & $\begin{array}{c}\text { Aluminum } \\
(\mathrm{mg} / \mathrm{kg})\end{array}$ & $\begin{array}{c}\text { Antimony } \\
\text { (mg/kg) }\end{array}$ & $\begin{array}{l}\text { Arsenic } \\
\text { (mg/kg) }\end{array}$ & $\begin{array}{l}\text { Barium } \\
\text { (mg/kg) }\end{array}$ & $\begin{array}{l}\text { Beryllium } \\
\text { (mg/kg) }\end{array}$ & $\begin{array}{l}\text { Cadmium } \\
\text { (mg/kg) }\end{array}$ & $\begin{array}{l}\text { Calcium } \\
\text { (mg/kg) }\end{array}$ & $\begin{array}{l}\text { Chromium } \\
\text { (mg/kg) }\end{array}$ & $\begin{array}{l}\text { Cobalt } \\
\text { (mg/kg) }\end{array}$ & $\begin{array}{l}\text { Copper } \\
\text { (mg/kg) }\end{array}$ & $\begin{array}{c}\text { Iron } \\
\text { (mg/kg) }\end{array}$ & $\begin{array}{c}\text { Lead } \\
(\mathrm{mg} / \mathrm{kg})\end{array}$ & $\begin{array}{l}\text { Lithium } \\
\text { (mg/kg) }\end{array}$ & $\begin{array}{c}\text { Magnesium } \\
\text { (mg/kg) }\end{array}$ \\
\hline 435250103270400 & L-1 & $06 / 20 / 2012$ & 13,000 & $<0.39$ & 14 & 180 & 0.63 & E0.190 & 9,400 & 21 & 6.9 & 23 & 21,000 & 11 & 17 & 4,300 \\
\hline 435300103270800 & L-2 & $06 / 20 / 2012$ & 13,000 & $<0.38$ & 34 & 110 & 0.91 & E0.220 & 3,300 & 17 & 5 & 24 & 13,000 & 9.3 & 22 & 3,100 \\
\hline 435302103265300 & L-5 & $06 / 20 / 2012$ & 9,600 & $<0.38$ & 13 & 110 & E0.45 & E0.098 & 1,600 & 18 & 4.9 & 7.6 & 13,000 & 6.8 & 28 & 3,500 \\
\hline 435257103271701 & L-9 & $11 / 13 / 2013$ & 14,000 & 1 & 7.3 & 190 & 0.8 & 2.5 & 2,900 & 22 & 5.9 & 11 & 18,000 & 12 & 36 & 4,000 \\
\hline 435259103271401 & L-10 & $11 / 13 / 2013$ & 13,000 & 1.4 & 3.3 & 140 & 0.7 & 1.5 & 2,000 & 14 & 4.3 & 6.7 & 18,000 & 4.6 & 32 & 4,600 \\
\hline 435300103271001 & L-11 & $11 / 13 / 2013$ & 7,800 & E0.6 & 4 & 99 & 0.5 & 1.4 & 1,800 & 13 & 4.8 & 5.3 & 11,000 & 9.8 & 20 & 2,500 \\
\hline 435245103273401 & L-12 & $11 / 13 / 2013$ & 4,900 & 3 & 24 & 100 & 0.7 & 2.2 & 4,800 & 6.2 & 1.9 & 83 & 15,000 & 100 & 18 & 750 \\
\hline 435231103265101 & G-1 & $06 / 20 / 2012$ & 9,300 & $<0.36$ & 7.8 & 150 & 0.56 & E0.180 & 2,000 & 18 & 5.5 & 14 & 13,000 & 8.9 & 24 & 3,200 \\
\hline 435234103274500 & S-1 & $06 / 20 / 2012$ & 13,000 & $<0.38$ & 24 & 160 & 0.85 & E0.230 & 3,100 & 24 & 6.3 & 15 & 19,000 & 9.6 & 42 & 4,800 \\
\hline 435327103290600 & P-2 & $06 / 06 / 2013$ & 2,200 & $<0.36$ & 19 & 35 & E0.24 & E0.130 & 1,200 & 3 & 1.8 & 7.3 & 4,100 & 4.2 & 9.1 & 620 \\
\hline 435044103241000 & $\mathrm{I}-1$ & $06 / 06 / 2013$ & 9,000 & $<0.35$ & 7.9 & 87 & 0.47 & E0.240 & 1,700 & 20 & 5.1 & 11 & 13,000 & 8 & 21 & 3,200 \\
\hline
\end{tabular}

\begin{tabular}{|c|c|c|c|c|c|c|c|c|c|c|c|c|c|c|}
\hline $\begin{array}{c}\text { USGS station } \\
\text { number }\end{array}$ & $\begin{array}{c}\text { Map } \\
\text { number } \\
\text { (fig. 1) }\end{array}$ & Date & $\begin{array}{c}\text { Manganese } \\
(\mathrm{mg} / \mathrm{kg})\end{array}$ & $\begin{array}{l}\text { Molybdenum } \\
(\mathrm{mg} / \mathrm{kg})\end{array}$ & $\begin{array}{l}\text { Nickel } \\
\text { (mg/kg) }\end{array}$ & $\begin{array}{c}\text { Potassium } \\
\text { (mg/kg) }\end{array}$ & $\begin{array}{c}\text { Selenium } \\
(\mathrm{mg} / \mathrm{kg})\end{array}$ & $\begin{array}{l}\text { Sodium } \\
\text { (mg/kg) }\end{array}$ & $\begin{array}{l}\text { Strontium } \\
(\mathrm{mg} / \mathrm{kg})\end{array}$ & $\begin{array}{l}\text { Thallium } \\
\text { (mg/kg) }\end{array}$ & $\begin{array}{c}\text { Titanium } \\
(\mathbf{m g} / \mathbf{k g})\end{array}$ & $\begin{array}{c}\text { Vanadium } \\
\text { (mg/kg) }\end{array}$ & $\begin{array}{c}\text { Zinc } \\
(\mathbf{m g} / \mathbf{k g})\end{array}$ & $\begin{array}{c}\text { Perchlorate } \\
(\mu \mathrm{g} / \mathrm{kg})\end{array}$ \\
\hline 435250103270400 & L-1 & $06 / 20 / 2012$ & 350 & E1.1 & 19 & 3,300 & $<0.88$ & E86 & 47 & $<0.66$ & 190 & 33 & 76 & E0.17 \\
\hline 435300103270800 & $\mathrm{~L}-2$ & 06/20/2012 & 250 & $<0.26$ & 15 & 3,200 & 1.6 & $<59$ & 24 & $<0.65$ & 370 & 24 & 38 & 0.86 \\
\hline 435302103265300 & L-5 & $06 / 20 / 2012$ & 310 & $<0.26$ & 12 & 4,000 & $<0.86$ & $<59$ & 11 & $<0.65$ & 700 & 19 & 41 & E0.14 \\
\hline 435257103271701 & L-9 & $11 / 13 / 2013$ & 450 & E0.2 & 17 & 3,300 & $<1.9$ & 74 & 17 & 5.8 & 1,100 & 26 & 55 & $<0.055$ \\
\hline 435259103271401 & $\mathrm{~L}-10$ & $11 / 13 / 2013$ & 540 & $<0.4$ & 13 & 5,700 & $<1.7$ & 55 & 16 & 5.7 & 1,200 & 13 & 30 & 2.3 \\
\hline 435300103271001 & L-11 & $11 / 13 / 2013$ & 580 & E0.1 & 12 & 2,600 & $<1.5$ & 49 & 10 & 3.2 & 630 & 14 & 41 & 0.77 \\
\hline 435245103273401 & $\mathrm{~L}-12$ & $11 / 13 / 2013$ & 290 & 0.5 & 13 & 770 & $<1.5$ & 54 & 17 & E0.5 & 120 & 5.5 & 120 & 1.7 \\
\hline 435231103265101 & G-1 & 06/20/2012 & 470 & $<0.24$ & 14 & 3,500 & $<0.81$ & $<56$ & 14 & $<0.61$ & 520 & 19 & 48 & 0.65 \\
\hline 435234103274500 & S-1 & $06 / 20 / 2012$ & 450 & $<0.26$ & 17 & 6,100 & $<0.87$ & $<60$ & 18 & $<0.66$ & 970 & 26 & 75 & 0.78 \\
\hline 435327103290600 & P-2 & 06/06/2013 & 240 & $<0.25$ & 6 & 780 & $<0.81$ & $<56$ & 5.1 & $<0.62$ & 100 & 4.6 & 16 & E0.29 \\
\hline 435044103241000 & $\mathrm{I}-1$ & 06/06/2013 & 270 & $<0.24$ & 16 & 3,700 & $<0.80$ & $<55$ & 9.8 & $<0.60$ & 550 & 19 & 40 & E0.21 \\
\hline
\end{tabular}

${ }^{1}$ Soil concentrations reported with an "E" preceding the value either (1) are below the minimum reporting level but greater than the established method detection limit, or (2) exceed the upper calibration range of the instrument. 


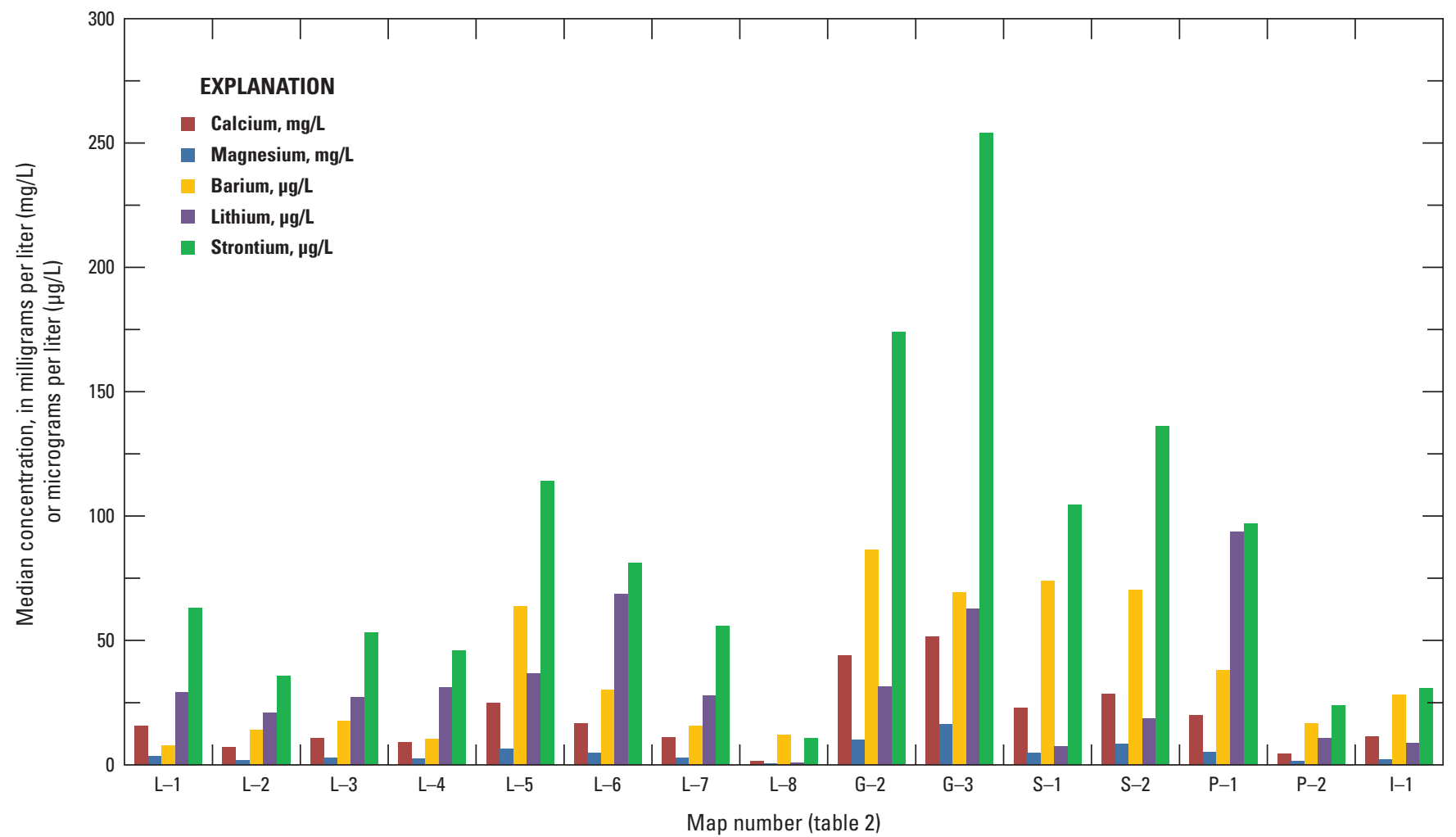

Figure 5. Median concentrations for five selected metals in samples from groundwater and surface-water sites within and adjacent to Mount Rushmore National Memorial, 2011-15.

\section{Groundwater Age Dating}

Multiple bottles for age-dating tracers (CFCs) were filled during sample collection and were analyzed to estimate the apparent age and detect possible contamination, as shown by the multiple results for each sample date in table 7. Apparent ages based on CFC-11 and CFC-12 generally were within 10 years of those reported for CFC-113. CFCs were analyzed for water samples collected from the two production wells (sites L-3 and L-4) in June and August 2012, and again in June 2013. The mean apparent age derived from CFC-113 results is about 1981-82 (plus or minus 2 years, standard deviation) for both production wells (table 7). CFC age-dating samples also were collected from the Grizzly Bear and Horsethief Lake Campground wells (sites G-3 and P-1, respectively). Agedating results for these sites using CFC-113 indicated a similar age for site G-3 (1980) in comparison to ages determined for the production wells, but a substantially older groundwater age for site P-1 (1969).

\section{Implications of Perchlorate in Water and Soil}

The perchlorate concentrations in groundwater and surface water within the Lafferty Gulch drainage basin during 2011-15 were greater than the EPA Interim Drinking Water Health Advisory of $15 \mu \mathrm{g} / \mathrm{L}$ (U.S. Environmental Protection
Agency, 2008). This advisory level is not currently (2015) a legally enforceable standard, but the regulation of perchlorate may occur in later years. Perchlorate concentrations in groundwater and surface-water samples collected at sites adjacent to Mount Rushmore National Memorial (reference samples) generally were less than $1 \mu \mathrm{g} / \mathrm{L}$, similar to those reported in other studies within the United States (Parker and others, 2007; Kalkhoff and others, 2010). The perchlorate concentrations in the water supply for Mount Rushmore National Memorial are of concern relative to the health advisory level; however, several assumptions warrant consideration when describing the potential risks. The Interim Drinking Water Health Advisory for perchlorate $(15 \mu \mathrm{g} / \mathrm{L})$ was developed by EPA for the subchronic drinking water exposure of the pregnant mother and her fetus (U.S. Environmental Protection Agency, 2008), which represents the highest risk category to this contamination. The calculation of this health advisory level includes the following assumptions: the no-effect level is 0.007 milligrams per kilogram per day, the assumed body weight is 70 kilograms ( 154 pounds), the daily water consumption is 2 liters ( 0.53 gallon), 62 percent of perchlorate exposure is from water ( 38 percent is from food), and there is a 10 -fold uncertainty factor to account for variability in responses among humans. Adjustment of these assumptions will yield different health advisory levels. For example, decreasing the water consumption from 2 to 1 liter ( 0.26 gallon) would result in 


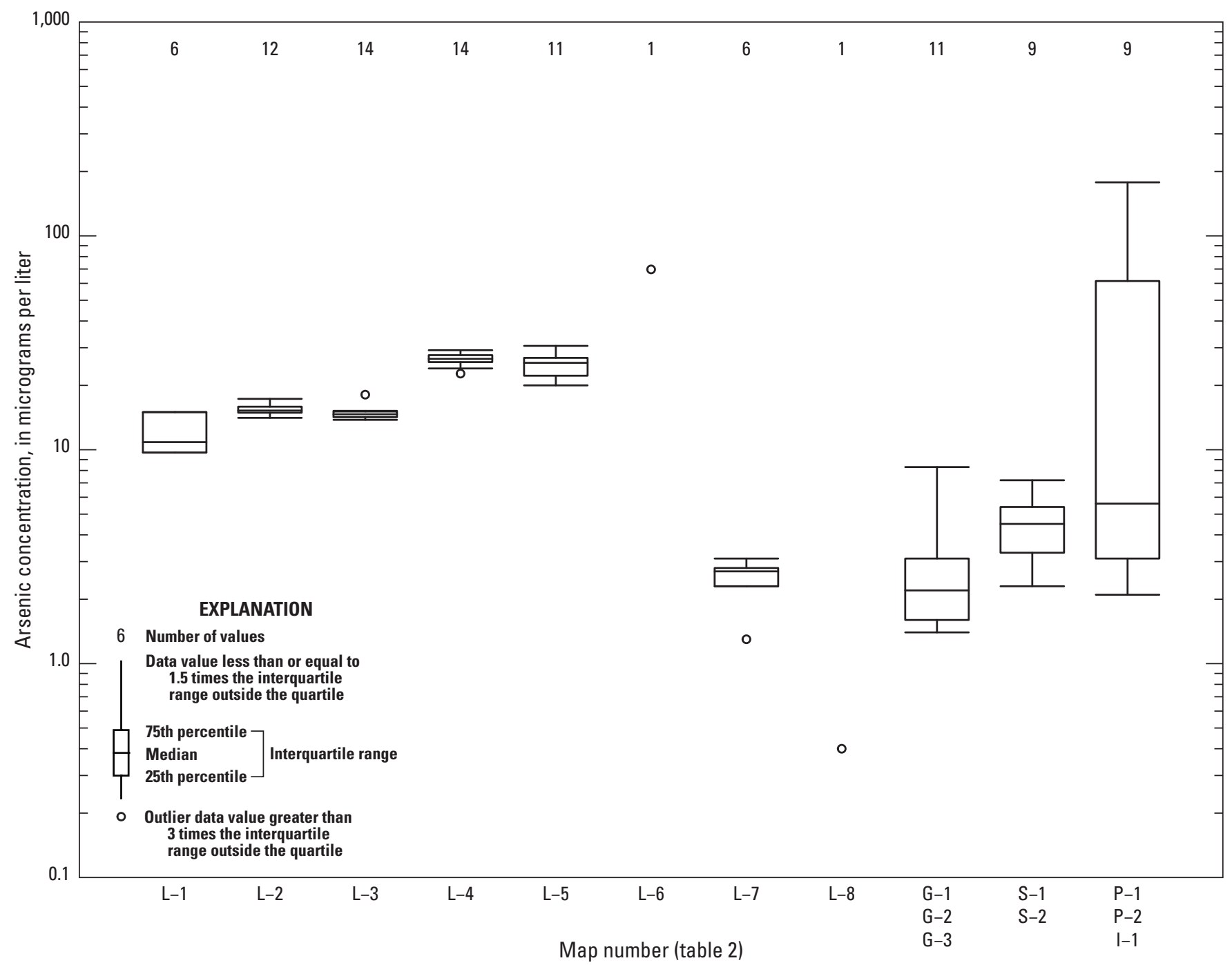

Figure 6. Boxplots of arsenic concentrations in groundwater and surface-water samples within and adjacent to Mount Rushmore National Memorial, 2011-15.

an equivalent health advisory level of $30 \mu \mathrm{g} / \mathrm{L}$. Most users of the water supply at Mount Rushmore National Memorial are temporary visitors who do not use the water for their full daily consumptive amount. Individuals at greater risk of exposure are the employees at the park, especially those who reside on site. To alleviate this risk, point-of-use water treatment systems (reverse osmosis membrane filters) have been installed at several Mount Rushmore National Memorial facility locations to reduce contaminant concentrations for those who use the water supply as their primary source (Rodney Hart, National Park Service, written commun., 2015). Urbansky and Schock (1999) describe several perchlorate treatment technologies in detail and list an example case of 80 percent perchlorate removal by reverse osmosis.

Perchlorate in soil samples were greatest in the Hall of Records Canyon (site L-12) and in the West Fork Lafferty Gulch drainage, about $750 \mathrm{ft}$ upgradient from the production wells (sites L-3 and L-4) and within the recharge zone for the groundwater. Lower perchlorate concentrations in other areas of the Lafferty Gulch drainage basin indicate that the contamination may have occurred in a random pattern as one would expect from the fallout from fireworks debris. The distance from the Hall of Records, where fireworks were launched, to the sites in West Fork Lafferty Gulch (sites L-2, L-9, L-10, and L-11) is about 2,000-2,500 ft, and the distance to the site in upper Starling Gulch drainage basin (site $\mathrm{S}-1$ ) is about $1,400 \mathrm{ft}$. The site farthest removed from the location of the launch site (site G-1) is about 3,500 ft from the Hall of Records. Wind direction and velocity were not documented as part of this study, but it is reasonable to deduce that firework debris could have been transported these distances given the typical launch trajectories and the 600-800-ft elevation change from the Hall of Records to the valleys below. 


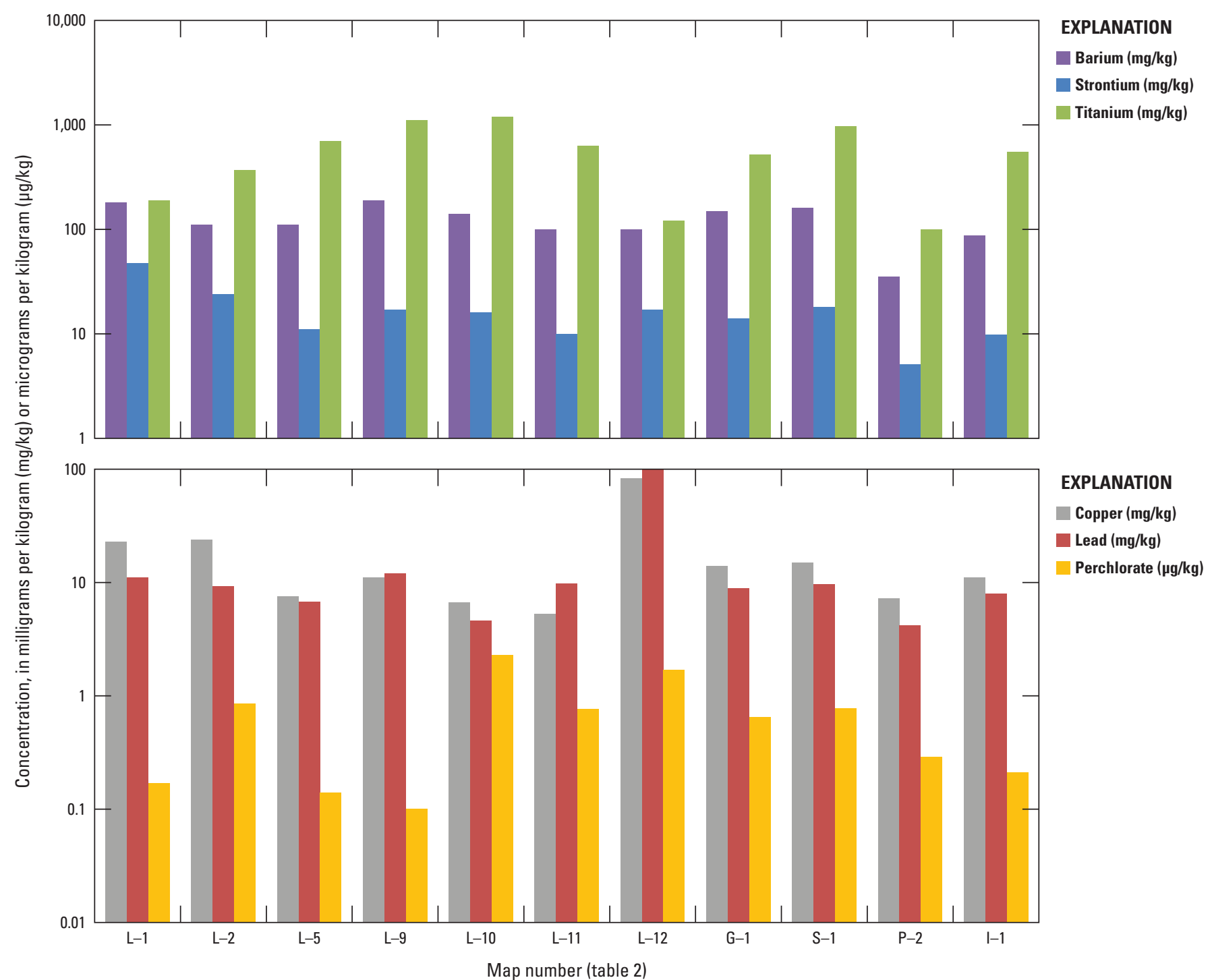

Figure 7. Concentrations of five selected metals and perchlorate in soil samples within Mount Rushmore National Memorial and reference sites, 2012-13.

It is important to note that no perchlorate concentration data in groundwater or surface water were available for the time period prior to 2011 within Mount Rushmore National Memorial or the adjacent drainage basins. Thus, it is difficult to directly establish background perchlorate concentrations for these study sites during the period prior to firework displays. An assumption is made that natural perchlorate concentrations within Mount Rushmore National Memorial would be much less than $1 \mu \mathrm{g} / \mathrm{L}$, which is similar to those from reference sites in the Pine and Iron Creek drainage basins and also previous studies that characterize perchlorate concentrations (Kalkhoff and others, 2010; Wilkin and others, 2007). Concentrations of metals in water and soil samples provide very little additional evidence to indicate these contaminants are associated with past firework displays. The information obtained from age dating of groundwater in the Lafferty Gulch drainage basin indicates that a large portion of the source water had recharged during and before the 1980s, prior to the firework displays during 1998-2009. A younger component to the groundwater likely recharged the aquifer during the period 1998-2009. Fractures exist in the mica schists, creating an aquifer from secondary porosity in rocks that otherwise would not contain enough porosity to provide a water supply. In this system, the groundwater is unconfined, and recharge occurs each year from the overlying area. The groundwater system at West Fork Lafferty Gulch is highly susceptible to contamination through recharge by way of the land surface and is isolated from downstream movement by an intrusive body acting as a dam (Powell and others, 1973), which may explain why contamination is not likely to disappear or disperse, as could happen in larger aquifer systems. The observed deposition of firework debris within the Lafferty Gulch drainage basin coupled with the lack of alternative perchlorate sources indicates that past firework displays are the most probable source of perchlorate contamination. 
Table 7. Groundwater age dating results from wells within and adjacent to Mount Rushmore National Memorial, 2012-2013.

[USGS, U.S. Geological Survey; mg/L, milligrams per liter; ${ }^{\circ} \mathrm{C}$, degrees Celsius; ft, feet above North Amercian Vertical Datum of 1988; CFC, chlorofluorocarbon; pg/kg, picograms per kilogram; --, not available]

\begin{tabular}{|c|c|c|c|c|c|c|c|c|c|c|c|c|c|c|c|}
\hline $\begin{array}{l}\text { USGS station } \\
\text { number }\end{array}$ & $\begin{array}{c}\text { Map } \\
\text { number } \\
\text { (fig. 1) }\end{array}$ & Date & Time & $\begin{array}{l}\text { Dissolved } \\
\text { carbon } \\
\text { dioxide } \\
\text { (mg/L) }\end{array}$ & $\begin{array}{c}\text { Dissolved } \\
\text { nitrogen } \\
\text { (mg/L) }\end{array}$ & $\begin{array}{c}\text { Dissolved } \\
\text { oxygen } \\
\text { (mg/L) }\end{array}$ & $\begin{array}{c}\text { Dissolved } \\
\text { argon } \\
\text { (mg/L) }\end{array}$ & $\begin{array}{c}\text { Recharge } \\
\text { temperature } \\
\left({ }^{\circ} \mathrm{C}\right)\end{array}$ & $\begin{array}{l}\text { Mean } \\
\text { recharge } \\
\text { altitude } \\
\text { (ft) }\end{array}$ & $\begin{array}{l}\text { CFC-11 } \\
\text { (pg/kg) }\end{array}$ & $\begin{array}{l}\text { CFC-12 } \\
\text { (pg/kg) }\end{array}$ & $\begin{array}{l}\text { CFC-113 } \\
\text { (pg/kg) }\end{array}$ & $\begin{array}{l}\text { CFC-11 } \\
\text { apparent } \\
\text { age }\end{array}$ & $\begin{array}{l}\text { CFC-12 } \\
\text { apparent } \\
\text { age }\end{array}$ & $\begin{array}{c}\text { CFC-113 } \\
\text { apparent } \\
\text { age }\end{array}$ \\
\hline \multicolumn{16}{|c|}{ Well \#1 } \\
\hline 435300103265001 & L-3 & $06 / 08 / 2012$ & 1015 & 44.9 & 18.95 & 2.3 & 0.657 & 6.8 & 5,500 & 360 & ${ }^{1} 2,500$ & 41 & 1975.5 & $\left({ }^{1}\right)$ & 1983 \\
\hline 435300103265001 & L-3 & $06 / 08 / 2012$ & 1016 & 45.1 & 18.79 & 2.6 & 0.655 & 6.8 & 5,500 & 350 & ${ }^{1} 2,500$ & 41 & 1975.5 & $\left({ }^{1}\right)$ & 1983 \\
\hline 435300103265001 & L-3 & $08 / 14 / 2012$ & 916 & 44.1 & 19.33 & 1.7 & 0.667 & 6.7 & 5,500 & -- & -- & -- & -- & -- & -- \\
\hline 435300103265001 & L-3 & $08 / 14 / 2012$ & 917 & 43.5 & 19.36 & 1.8 & 0.664 & 6.7 & 5,500 & 270 & ${ }^{1} 1,600$ & 31 & 1973.5 & $\left({ }^{1}\right)$ & 1980.5 \\
\hline 435300103265001 & L-3 & $08 / 14 / 2012$ & 919 & -- & -- & -- & -- & -- & -- & 270 & ${ }^{1} 1,600$ & 30 & 1973 & (1) & 1980.5 \\
\hline 435300103265001 & L-3 & $06 / 04 / 2013$ & 1101 & 44.2 & 19.42 & 3.1 & 0.655 & 7.6 & 5,500 & 390 & 12,400 & 40 & 1977 & (1) & 1983 \\
\hline 435300103265001 & L-3 & $06 / 04 / 2013$ & 1102 & 44 & 19.66 & 3.1 & 0.662 & 7.6 & 5,500 & 370 & 12,400 & 38 & 1976 & $(1)$ & 1982.5 \\
\hline \multirow[t]{3}{*}{435300103265001} & L-3 & $06 / 04 / 2013$ & 1104 & -- & -- & -- & -- & 7.6 & 5,500 & 390 & ${ }^{1} 2,400$ & 39 & 1977 & $(1)$ & 1983 \\
\hline & & & & & & & & & & Mean & & & 1975 & -- & 1982 \\
\hline & & & & & & & & & & \multicolumn{3}{|c|}{ Standard deviation (years) } & 1.6 & -- & 1.2 \\
\hline \multicolumn{16}{|c|}{ Well \#2 } \\
\hline 435302103270501 & L-4 & $06 / 08 / 2012$ & 1145 & -- & -- & -- & -- & 8.2 & 5,500 & 250 & ${ }^{1} 400$ & 34 & 1973.5 & $(1)$ & 1982 \\
\hline 435302103270501 & L-4 & $06 / 08 / 2012$ & 1146 & 32.8 & 16.88 & 4.7 & 0.61 & 8.2 & 5,500 & 190 & 1370 & 24 & 1971.5 & (1) & 1980 \\
\hline 435302103270501 & L-4 & $06 / 08 / 2012$ & 1147 & 29.7 & 16.93 & 4.7 & 0.613 & 8.2 & 5,500 & 240 & ${ }^{1} 360$ & 32 & 1973 & $\left({ }^{1}\right)$ & 1982 \\
\hline 435302103270501 & L-4 & $06 / 08 / 2012$ & 1148 & -- & -- & -- & -- & 8.2 & 5,500 & 320 & 1370 & 42 & 1975 & $(1)$ & 1984 \\
\hline 435302103270501 & L-4 & $08 / 14 / 2012$ & 831 & 32 & 18.86 & 2.3 & 0.652 & -- & -- & -- & -- & -- & -- & -- & -- \\
\hline 435302103270501 & L-4 & $08 / 14 / 2012$ & 832 & 32 & 18.53 & 2.6 & 0.645 & -- & -- & -- & -- & -- & -- & -- & -- \\
\hline 435302103270501 & L-4 & $08 / 14 / 2012$ & 857 & -- & -- & -- & -- & 7.4 & 5,500 & 280 & 260 & 40 & 1973.5 & 1986 & 1983 \\
\hline 435302103270501 & L-4 & $08 / 14 / 2012$ & 858 & -- & -- & -- & -- & 7.4 & 5,500 & 170 & 250 & 24 & 1970.5 & 1985.5 & 1979 \\
\hline 435302103270501 & L-4 & $08 / 14 / 2012$ & 859 & -- & -- & -- & -- & 7.4 & 5,500 & 270 & 260 & 38 & 1973.5 & 1986.5 & 1983 \\
\hline 435302103270501 & L-4 & $06 / 04 / 2013$ & 1121 & 33.9 & 17.26 & 2.5 & 0.625 & -- & -- & -- & -- & -- & -- & -- & -- \\
\hline 435302103270501 & L-4 & $06 / 04 / 2013$ & 1122 & 33.6 & 17.16 & 2.5 & 0.624 & 7.0 & 5,500 & 200 & ${ }^{1} 640$ & 24 & 1971.5 & $\left({ }^{1}\right)$ & 1979 \\
\hline \multirow[t]{3}{*}{435302103270501} & L-4 & $06 / 04 / 2013$ & 1124 & -- & -- & -- & -- & 7.0 & 5,500 & 200 & ${ }^{1} 630$ & 25 & 1971.5 & $\left({ }^{1}\right)$ & 1979 \\
\hline & & & & & & & & & & Mean & & & 1973 & 1986 & 1981 \\
\hline & & & & & & & & & & \multicolumn{3}{|c|}{ Standard deviation (years) } & 1.4 & 0.5 & 2.0 \\
\hline \multicolumn{16}{|c|}{ Grizzly Bear Campground Well } \\
\hline 435242103261801 & G-3 & $06 / 04 / 2013$ & 1001 & 14.4 & 23.96 & 11 & 0.778 & 3.6 & 5,040 & 300 & 270 & 37 & 1972.5 & 1982 & 1980 \\
\hline 435242103261801 & G-3 & $06 / 04 / 2013$ & 1002 & 14.7 & 22.51 & 9.9 & 0.755 & -- & -- & -- & -- & -- & -- & -- & -- \\
\hline 435242103261801 & G-3 & $06 / 04 / 2013$ & 1003 & -- & -- & -- & -- & 3.6 & 5,040 & 280 & 260 & 36 & 1972 & 1981.5 & 1980 \\
\hline \multirow[t]{3}{*}{435242103261801} & G-3 & $06 / 04 / 2013$ & 1004 & -- & -- & -- & -- & 3.6 & 5,040 & 280 & 260 & 36 & 1972 & 1981 & 1980 \\
\hline & & & & & & & & & & Mean & & & 1972 & 1982 & 1980 \\
\hline & & & & & & & & & & \multicolumn{3}{|c|}{ Standard deviation (years) } & 0.3 & 0.5 & 0.0 \\
\hline \multicolumn{16}{|c|}{ Horsethief Lake Campground Well } \\
\hline 435342103285801 & P-1 & $06 / 06 / 2013$ & 1501 & 76.8 & 23.51 & 0.3 & 0.742 & 5.2 & 6,060 & 61 & 39 & 7.4 & 1963.5 & 1963.5 & 1969.5 \\
\hline 435342103285801 & P-1 & $06 / 06 / 2013$ & 1502 & 77.8 & 23.83 & 0.3 & 0.749 & 5.2 & 6,060 & 59 & 38 & 8 & 1963 & 1963 & 1970 \\
\hline \multirow[t]{3}{*}{435342103285801} & P-1 & $06 / 60 / 2013$ & 1503 & -- & -- & -- & -- & 5.2 & 6,060 & 51 & 39 & 6.8 & 1962.5 & 1963 & 1968.5 \\
\hline & & & & & & & & & & Mean & & & 1963 & 1963 & 1969 \\
\hline & & & & & & & & & & \multicolumn{3}{|c|}{ Standard deviation (years) } & 0.5 & 0.3 & 0.8 \\
\hline
\end{tabular}




\section{Summary and Conclusions}

Mount Rushmore National Memorial is located in the east-central part of the Black Hills region of South Dakota and is challenged to provide drinking water to about 3 million annual visitors and year-round park personnel. About 7 million gallons of drinking water each year are pumped from two production wells (200 and 500 feet deep) located about 0.5 mile northeast of the memorial and visitor center within the Lafferty Gulch drainage basin. An environmental concern to water resources within Mount Rushmore National Memorial has been the annual aerial release of fireworks at the memorial for the Independence Day holiday during 1998-2009. A major concern by park management is the contamination of groundwater and surface water by perchlorate and metals associated with fireworks displays. Perchlorate does not currently have a regulated maximum contaminant level for drinking water supplies from the U.S. Environmental Protection Agency, but an interim Health Advisory level was set at 15 micrograms per liter $(\mu \mathrm{g} / \mathrm{L})$. A study by the U.S. Geological Survey, in cooperation with the National Park Service, was completed to characterize the occurrence of perchlorate and selected metals (constituents commonly associated with fireworks) in groundwater and surface water within and adjacent to Mount Rushmore National Memorial during 2011-15.

This report provides a characterization of perchlorate and selected metals in groundwater and surface water within and adjacent to Mount Rushmore National Memorial during 2011-15. Concentrations of perchlorate and metals were measured in 106 water samples (collected from 6 groundwater sites and 14 surface-water sites) and 11 soil samples (collected from 11 soil sites). Sites were selected in three major drainage basins within the park boundary, and sites also were selected in drainages adjacent to the park to be used as reference comparisons. Water-quality constituents measured included field properties (dissolved oxygen, $\mathrm{pH}$, specific conductance, and water temperature), perchlorate, selected metals, and chlorofluorocarbons (groundwater sites only). Perchlorate and selected metals were analyzed in soil samples collected from within the park and adjacent drainages.

Within the Mount Rushmore National Memorial boundary, perchlorate concentrations were greatest in the Lafferty Gulch drainage basin, ranging from less than 0.20 to $38 \mu \mathrm{g} / \mathrm{L}$ in groundwater samples and from 2.2 to $54 \mu \mathrm{g} / \mathrm{L}$ in surfacewater samples. Samples from the two surface-water sites in the Starling Gulch drainage basin also had some evidence of perchlorate contamination, with concentrations ranging from 0.61 to $19 \mu \mathrm{g} / \mathrm{L}$. All groundwater and surface-water samples within the drainage basin for the unnamed tributary to Grizzly Bear Creek and reference sites outside the park boundary had perchlorate concentrations less than $0.20 \mu \mathrm{g} / \mathrm{L}$. The median perchlorate concentration in samples collected from the 200foot production well (Well 1) was $23 \mu \mathrm{g} / \mathrm{L}$, and the median perchlorate concentration in samples collected from the 500foot production well (Well 2) was $6.1 \mu \mathrm{g} / \mathrm{L}$. Median perchlorate concentrations in samples of the treated groundwater at
Mount Rushmore National Memorial were $20 \mu \mathrm{g} / \mathrm{L}$, similar to the median concentrations $(23 \mu \mathrm{g} / \mathrm{L})$ from Well 1 , which was the predominant source of water supply during the study period (2011-15). Samples of springflow collected upstream from the production wells in the West Fork Lafferty Gulch drainage had the greatest median perchlorate concentration $(47 \mu \mathrm{g} / \mathrm{L})$. The groundwater site within Lafferty Gulch drainage basin but downstream from the park boundary also had a perchlorate concentration less than $0.20 \mu \mathrm{g} / \mathrm{L}$ in the one sample collected at the site. Perchlorate concentrations changed little during the 2011-15 study period, although concentrations measured in May and June during 2012-14 typically were greater than concentrations measured during July and August of the same year. Water samples collected at reference sites outside the park boundary generally had concentrations of metals within the same range of those sites within the Mount Rushmore National Memorial boundary, indicating little evidence of metal contamination due to anthropogenic factors within the park boundary. In contrast, perchlorate concentrations in samples collected within Mount Rushmore National Memorial were about one order of magnitude higher than perchlorate concentrations in samples outside of the park unit.

Perchlorate concentrations in soil were greatest in the West Fork Lafferty Gulch drainage; the soil samples were collected from sites that are topographically higher than the two production wells. Perchlorate in soil samples from two of the sites upstream from wells in West Fork Lafferty Gulch drainage were 2.3 and 1.7 micrograms per kilogram $(\mu \mathrm{g} / \mathrm{kg})$, whereas concentrations at reference soil sites were about an order of magnitude less $(0.29$ and $0.21 \mu \mathrm{g} / \mathrm{kg})$. Concentrations of the 25 metals analyzed in soil samples typically were similar among sites; however, 22 of 25 metal concentrations in soil were greater at sites within Mount Rushmore National Memorial than in samples collected at reference sites. Copper and lead concentrations (83 and 100 milligrams per kilogram, respectively) at the site closest to the location of the fireworks launches were about an order of magnitude greater than concentrations at all other sites. Titanium and barium concentrations were greatest in soil samples from two sites in the Lafferty Gulch drainage basin compared to all other sites.

The perchlorate concentrations in groundwater and surface water within the Lafferty Gulch drainage basin during 2011-15 were greater than the EPA Interim Drinking Water Health Advisory of $15 \mu \mathrm{g} / \mathrm{L}$. Perchlorate in soil samples were greatest in the Hall of Records Canyon (at the site closest to the location of the fireworks launches) and in West Fork Lafferty Gulch drainage, about 750 feet upgradient from the production wells used for water supply at Mount Rushmore National Memorial; however, lower concentrations in other areas of the Lafferty Gulch drainage basin indicate that the contamination may have occurred in a random pattern as one would expect from the fallout from fireworks debris. The groundwater system in West Fork Lafferty Gulch drainage is highly susceptible to contamination through recharge by way of the land surface and is isolated from downstream movement by an intrusive body acting as a dam, which may explain why 
a contamination problem is not likely to disappear or disperse, as could happen in larger aquifer systems. The observed deposition of firework debris within the Lafferty Gulch drainage basin coupled with the lack of alternative perchlorate sources indicates that past firework displays are the most probable source of perchlorate contamination.

\section{References Cited}

Betemariam, Hailemelekot, Davis, A.R., Dixon, D., and Hanson, M.R., 2010, Arsenic contamination in the Mount Rushmore area and proposed removal techniques: Geological Society of America Abstracts with Programs, v. 42, no. 1. [Also available at https://gsa.confex.com/gsa/2010RM/finalprogram/abstract_172071.htm.]

California Department of Public Health, 2007, Perchlorate in drinking water: accessed December 1, 2015, at http://www. cdph.ca.gov/services/DPOPP/regs/Pages/R-16-04-PerchlorateinDrinkingWater.aspx.

Carter, J.M., Driscoll, D.G., Williamson, J.E., and Lindquist, V.A., 2002, Atlas of water resources in the Black Hills area, South Dakota: U.S. Geological Survey Hydrologic Investigations Atlas HA-747, 120 p. [Also available at http://pubs. usgs.gov/ha/ha747/.]

Casiday, Rachel, and Frey, Regina, 1998, Acid rain: St. Louis, Missouri, Department of Chemistry, Washington University, accessed October 22, 2015, at http://www.chemistry.wustl. edu/ edudev/LabTutorials/Water/FreshWater/acidrain.html.

Conkling, J.A., 1990, Pyrotechnics: Scientific American, v. 263 , no. 1 , p. $96-102$.

Driscoll, D.G., Carter, J.M., Williamson, J.E., and Putnam, L.D., 2002, Hydrology of the Black Hills area, South Dakota: U.S. Geological Survey Water-Resources Investigations Report 02-4094, 150 p. [Also available at http://pubs. usgs.gov/wri/wri024094/.]

Duke, E.F., Papike, J.J., and Laul, J.C., 1992, Geochemistry of a boron-rich peraluminous granite pluton-The Calamity Peak layered granite-pegmatite complex, Black Hills, South Dakota: Canadian Mineralogist, v. 30, no. 3, p. 811-833.

Gajjala, Skikala, 2011, Perchlorate (anaerobic) degradation pathway map: accessed December 19, 2013, at http:// eawag-bbd.ethz.ch/pco/pco_map.html.
Garbarino, J.R., and Struzeski, T.M., 1998, Methods of analysis by the U.S. Geological Survey National Water Quality Laboratory-Determination of elements in wholewater digests using inductively coupled plasma-optical emission spectrometry and inductively coupled plasmamass spectrometry: U.S. Geological Survey Open-File Report 98-165, 101 p. [Also available at http://wwwnwql. cr.usgs.gov/rpt.shtml?OFR-98-165.]

Hem, J.D., 1985, Study and interpretation of the chemical characteristics of natural water ( $3 \mathrm{~d}$ ed.): U.S. Geological Survey Water-Supply Paper 2254, 264 p. [Also available at http://pubs.usgs.gov/wsp/wsp2254/ ]

Hinkle, S.R., and Snyder, D.T., 1997, Comparison of chlorofluorocarbon-age dating with particle-tracking results of a regional ground-water flow model of the Portland Basin, Oregon and Washington: U.S. Geological Survey WaterSupply Paper 2483, 47 p. [Also available at http://pubs. usgs.gov/wsp/2483/report.pdf.]

Interstate Technology and Regulatory Council, 2012, Incremental sampling methodology: accessed January 11, 2013, at http://www.itrcweb.org/ism-1/.

Kalkhoff, S.J., Stetson, S.J., Lund, K.D., Wanty, R.B., and Linder, G.L., 2010, Perchlorate data for streams and groundwater in selected areas of the United States, 2004: U.S. Geological Survey Data Series 495, 43 p. with appendix. [Also available at http://pubs.usgs.gov/ds/495/.]

Massachusetts Department of Environmental Protection, 2006, Inorganic chemical Maximum Contaminant Levels, monitoring requirements and analytical methods: accessed December 1, 2015, at http://www.mass.gov/eea/docs/dep/ water/laws/i-thru-z/perchlorate-310cmr22-07282006.pdf.

Massachusetts Department of Environmental Protection, 2007, Evaluation of perchlorate contamination at a fireworks display, Dartmouth, Massachusetts: accessed October 22, 2015, at http://www.mass.gov/eea/docs/dep/cleanup/ sites/umdrep.pdf.

Mueller, D.K., Schertz, T.L., Martin, J.D., and Sandstrom, M.W., 2015, Design, analysis, and interpretation of field quality-control data for water-sampling projects: U.S. Geological Survey Techniques and Methods, book 4, chap. C4, 54 p. [Also available at http://dx.doi.org/10.3133/tm4C4.]

Murray, B.T., 2010, N.J. environmental chief refuses tougher drinking water standard for perchlorates: The Star-Ledger, accessed December 1, 2015, at http://www.nj.com/news/ index.ssf/2010/04/nj_environmental_chief_refuses.html. 
National Oceanic and Atmospheric Administration, 2015, Daily summaries station details: National Climatic Data Center, accessed July 21, 2015, at http://www. ncdc.noaa.gov/cdo-web/datasets/GHCND/stations/ GHCND:USC00395870/detail.

National Park Service, 2016, Mount Rushmore National Memorial carving history: accessed February 25, 2016, at http://www.nps.gov/moru/learn/historyculture/carvinghistory.htm.

Parker, D.R., Seyfferth, A.L., and Reese, B.K., 2007, Perchlorate in groundwater-A synoptic survey of "pristine" sites in the coterminous United States: Environmental Science and Technology, v. 42 no.5, p. 1465-1471. [Also available at http://dx.doi.org/10.1021/es7021957.]

Powell, J.E., Norton, J.J., and Adolphson, D.G., 1973, Water resources and geology of Mount Rushmore National Memorial, South Dakota: U.S. Geological Survey Water-Supply Paper 1865, 50 p. [Also available at https://pubs.er.usgs. gov/publication/wsp1865.]

Rahn, P.H., 1990, Ground-water recharge at Mount Rushmore: Proceedings of the South Dakota Academy of Sciences, v. 69 , p. $129-138$.

Rajagopalan, Srinath, Anderson, T.A., Fahquist, Lynne, Rainwater, K.A., Ridley, Moira, and Jackson, W.A., 2006, Widespread presence of naturally occurring perchlorate in High Plains of Texas and New Mexico: Environmental Science and Technology, v. 40, no. 10, p. 3156-3162. [Also available at http://dx.doi.org/10.1021/es052155i.]

Redden, J.A., and DeWitt, Ed, 2008, Maps showing geology, structure, and geophysics of the central Black Hills, South Dakota: U.S. Geological Survey Scientific Investigations Map 2777, 44 p. pamphlet, 2 sheets. [Also available at http://pubs.usgs.gov/sim/2777/.]

Russell, M.S., 2000, The chemistry of fireworks: Cambridge, U.K., Royal Society of Chemistry, 117 p.

Sandeep, M., and Patiño, R., 2007, Effects of prolonged exposure to perchlorate on thyroid and reproduction function in zebrafish: Toxicological Sciences, v. 96, no. 2, p. 246-254. [Also available at http://dx.doi.org/10.1093/toxsci/kfm001.]

Smith, P.N., Theodorakis, C.W., Anderson, T.A., and Kendall, R.J., 2001, Preliminary assessment of perchlorate in ecological receptors at the Longhorn Army Ammunition Plant (LHAAP), Karnack, Texas: Ecotoxicology, v. 10, no. 5, p. 305-313. [Also available at http://dx.doi. org/10.1023/A:1016715502717.]
South Dakota Department of Environment and Natural Resources, 2016, Water well completion reports: accessed March 16, 2016, at https://denr.sd.gov/wrimage/WellCompletionReports/images15k/00002650.pdf.

Steinhauser, G., Sterba, J.H., Foster, M., Grass, F., and Bichler, M., 2008, Heavy metals from pyrotechnics in New Year's Eve snow: Atmospheric Environment, v. 42, no. 37, p. 8616-8622. [Also available at http://dx.doi.org/ doi:10.1016/j.atmosenv.2008.08.023.]

Timme, P.J., 1995, National Water Quality Laboratory, 1995 services catalog: U.S. Geological Survey Open-File Report 95-352, $92 \mathrm{p}$.

Tipton, D.K., Rolston, D.E., and Scow, K.M. 2003, Transport and biodegradation of perchlorate in soils: Journal of Environmental Quality, v. 32, no.1, p. 40-46. [Also available at http://dx.doi.org/10.2134/jeq2003.4000.]

Trumpolt, C.W., Crain, M., Cullison, G.D., Flanagan, S.J.P., Siegel, L., and Lathrop, S., 2005, Perchorate-Sources, uses, and occurrences in the environment: Remediation Journal, v. 16, no. 1, p. 65-89. [Also available at http:// dx.doi.org/10.1002/rem.20071.]

Urbansky, E.T., 1998, Perchlorate chemistry-Implications for analysis and remediation: Bioremediation Journal, v. 2, no. 2, p. 81-95. [Also available at http://dx.doi. org/10.1080/10889869891214231.]

Urbansky, E.T., 2002, Perchlorate as an environmental contaminant: Environmental Science and Pollution Research, v. 9, no. 3, p. 187-192. [Also available at http://dx.doi. org/10.1007/BF02987487.]

Urbansky, E.T., and Schock, M.R., 1999, Issues in managing the risks associated with perchlorate in drinking water: Journal of Environmental Management, v. 56, no. 2, p. 79-95. [Also available at http://dx.doi.org/10.1006/ jema.1999.0274.]

U.S. Environmental Protection Agency, 1996, EPA Method 6010B: accessed March 20, 2013, at http://www.caslab. com/EPA-Method-6010B/.

U.S. Environmental Protection Agency, 2005, Perchlorate treatment technology update-Federal facilities forum issue paper: EPA-542-R-05-015, accessed October 22, 2015, at https://clu-in.org/download/remed/542-r-05-015.pdf.

U.S. Environmental Protection Agency, 2006, Drinking water contaminants - Standards and regulations: accessed March 8, 2013, at http://water.epa.gov/drink/contaminants/ index.cfm. 
U.S. Environmental Protection Agency, 2007, Method 6860 - Perchlorate in water, soils and solid wastes using ion chromatography/electrospray ionization/mass spectrometry: accessed December 2, 2015, at https:/www.epa.gov/sites/ production/files/2015-12/documents/6860.pdf.

U.S. Environmental Protection Agency, 2008, Interim drinking water health advisory for perchlorate: Washington, D.C., U.S. Environmental Protection Agency, Office of Water, EPA 822-R-08-025, accessed October 22, 2015, at http:// www2.epa.gov/ccl/perchlorate.

U.S. Environmental Protection Agency, 2015, Contaminant candidate list 3-CCL 3: accessed October 22, 2015, at http://www2.epa.gov/ccl/contaminant-candidate-list3-ccl-3.

U.S. Geological Survey, variously dated, National field manual for the collection of water-quality data: U.S. Geological Survey Techniques of Water-Resources Investigations, book 9, chaps. A1-A9, accessed January 23, 2013 at http:// pubs.water.usgs.gov/twri9A.
U.S. Geological Survey, 2015, The Reston Groundwater Dating Laboratory-Chlorofluorocarbon analysis: accessed October 22, 2015, at http://water.usgs.gov/lab/chlorofluorocarbons/.

U.S. Geological Survey, 2016a, National Water Information System: accessed February 23, 2016 at http://waterdata. usgs.gov/sd/nwis/.

U.S. Geological Survey, 2016b, USGS water-quality data for South Dakota: accessed February 18, 2016, at http://waterdata.usgs.gov/sd/nwis/qw.

Wilkin, R.T., Fine, D.D., and Burnett, N.G., 2007, Perchlorate behavior in a municipal lake following firework displays: Environmental Science and Technology, v. 41, no. 11, p. 3966-3971. [Also available at http://dx.doi.org/10.1021/ es0700698.]

Yu, Lu, Cañas, J.E., Cobb, G.P., Jackson, W.A., and Anderson, T.A., 2004, Uptake of perchlorate in terrestrial plants: Ecotoxicology and Environmental Safety, v. 58, p. 44-49. [Also available at http://dx.doi.org/10.1016/S01476513(03)00108-8.] 


\section{Appendix 1}

A complete listing of the water-quality data for samples collected from the study area are presented in the Microsoft ${ }^{\circledR}$ Excel file available at http://dx.doi.org/10.3133/sir20165030. The Microsoft巴 Excel file contains the following two worksheets:

1. "Info" worksheet describes contents of the Microsoft@ Excel file and abbreviations, and

2. "W0_data" worksheet contains water-quality sample results sorted by sampling site. 
Publishing support provided by: Rolla Publishing Service Center

For more information concerning this publication, contact: Director, USGS South Dakota Water Science Center 1608 Mountain View Road

Rapid City, South Dakota 57702

(605) 394-3200

Or visit the South Dakota Water Science Center Web site at: http://sd.water.usgs.gov/ 
Back cover photographs. Profile views of George Washington, Mount Rushmore National Memorial (left, photograph by Brian Engle; right, photograph by Galen Hoogestraat) 

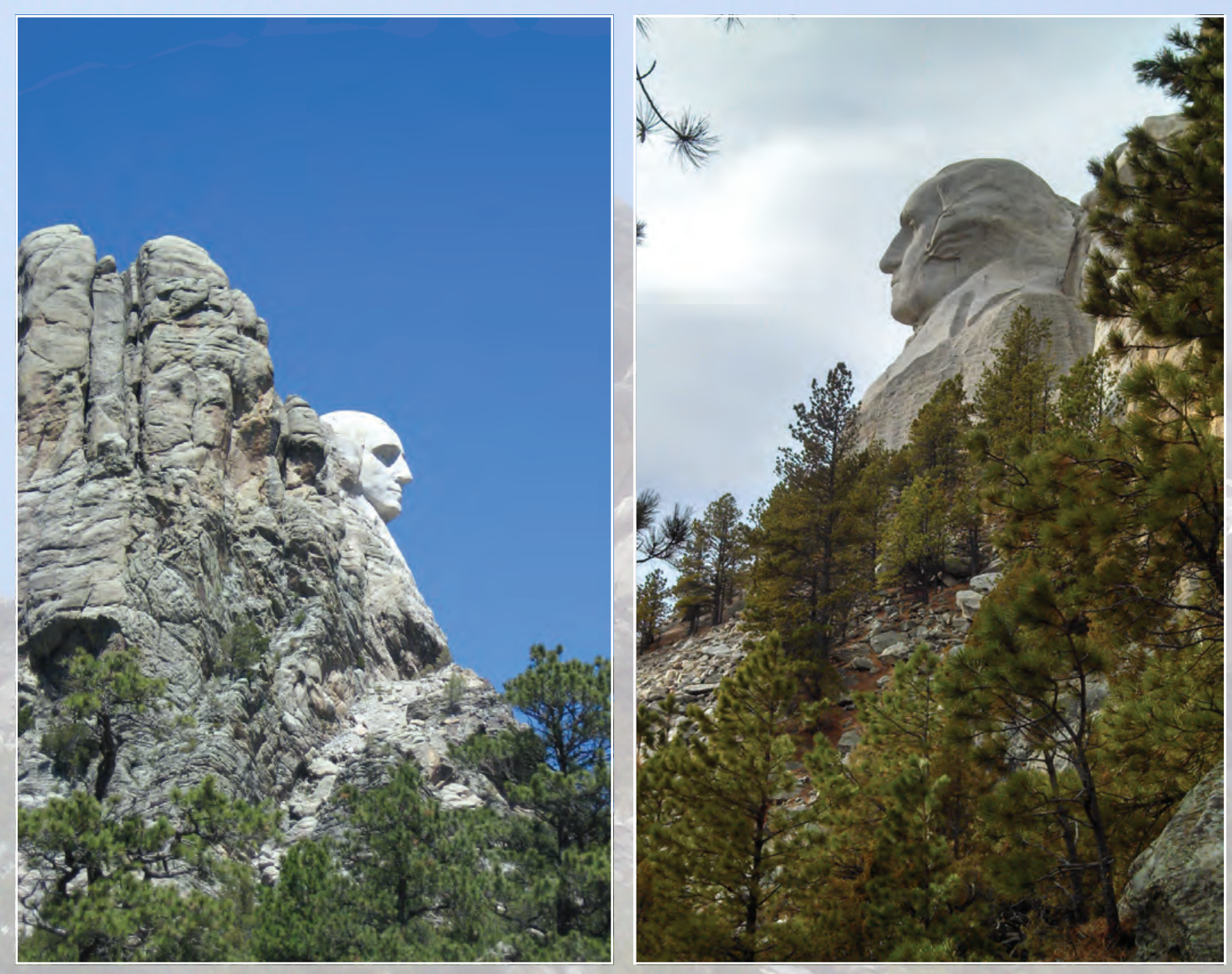